\title{
The Use of Torture in the Fight AgAINST TERrorisM
}

\author{
Aniel de Beer \\ Research Associate: South African Research Chair in \\ International Law, University of Johannesburg, RSA \\ anieldebeer@outlook.com.
}

DE BEER, Aniel. The Use of Torture in the Fight against Terrorism. International and Comparative Law Review, 2018, vol. 18, no. 1, pp. 51-88. DOI: 10.2478/iclr2018-0026.

\begin{abstract}
Summary: The argument that torture could be permissible in exceptional cases, such as the fight against terrorism, has been increasingly present in the rhetoric of politicians. President Trump's belief in the effectiveness of torture has renewed the debate about how far interrogators may go to extract information as part of counter-terrorism measures. Added to this his nomination of Ms Gina Haspel for the position of director of the Central Intelligence Agency, where Ms Haspel has been accused of being involved in the torture of terrorist suspects, and the debate over what constitutes torture and what is permissible in the fight against terrorism is reignited. This article firstly considers whether there has been any evolution with regards to the understanding of which acts constitute torture, and in particular whether severe pain and suffering remains a requirement for an act to constitute torture. Secondly, it enquires whether any limitation of the prohibition of torture is permissible in the fight against terrorism, in light of the universal condemnation of terrorism and the threat it poses to global peace and security.
\end{abstract}

Keywords: Human dignity, jus cogens, Guantanamo Bay, terrorism, torture, waterboarding

\section{Introduction}

There have been, and are now, certain foreign nations ... which convict individuals with testimony obtained by police organizations possessed of unrestrained power to seize persons ... hold them in secret custody and wring from them confessions by physical or mental torture. So long as the Constitution remains the basic law of this Republic, America will not have that kind of government. ${ }^{1}$

In the years since the statement by the United States (US) Supreme Court in Ashcraft $v$ Tennessee and after the terrorist attacks of 9/11, there may be doubts as to whether this statement holds true. Terrorism has become a massive threat to global peace and security and is universally condemned. ${ }^{2}$ The statistics are

1 Ashcraft v Tennessee 322 US 143, 155 (1944).

2 See Flatow v Islamic Republic of Iran 999 F Supp 23 (DDC 1998) ('Terrorism has achieved the status of almost universal condemnation, as have slavery, genocide, and piracy, and the 
stark. In the last few years, numerous terrorist attacks have been carried out in Nigeria by the Islamist militant group Boko Haram, ${ }^{3}$ and in southern Somalia and Kenya by the Al-Qaida affiliated al Shabaab group. This included an attack by Al Shabaab on an African Union convoy in July 2017 in Somalia ${ }^{4}$ and the beheadings of men in villages and killing of policemen in Kenya by al Shabaab. ${ }^{5}$

In Europe, terror attacks perpetrated by assailants who had sworn allegiance to the Islamic State of Iraq and Syria seemed to continue unabated. ${ }^{6}$ In 2016, bomb blasts shook Brussels, ${ }^{7}$ terrorists killed an elderly priest at a church in Normandy, France by stabbing him in the chest and slitting his throat ${ }^{8}$ and a truck deliberately ploughed into a crowd in Nice, France, killing 84 people and injuring hundreds. ${ }^{9}$ In November 2016, bombings and mass shootings erupted at various venues in Paris, killing close to 130 people and injuring hundreds more. ${ }^{10}$ In 2017, a van hit pedestrians on London Bridge, before three men exited the vehicle and began stabbing people in nearby market, while an attack in Manchester left 22 people dead and 59 injured after a suicide bomber targeted children and young adults at a concert. ${ }^{11}$

The United Nations Security Council (UNSC) has taken measures which are legally binding on all states to address terrorism as a threat to global peace and security. ${ }^{12}$ For example, resolution 1373 of 2001 is binding on all states and requires all member states to make terrorism a serious crime in domestic legis-

terrorist is the modern era's hosti humani generis - an enemy of all mankind').

3 AL JAZEERA. At least 11 civilians killed in Boko Haram attack, 2 September 2017, [online]. Available at: http://www.aljazeera.com/news/2017/09/11-civilians-killed-bokoharam-attack-170902043943431.html. Accessed: 1 October 2017.

4 BERI, Ruchita. Rise of Terrorism in Africa. Institute for Defence Studies and Analyses, 13 April 2017, [online]. Available at: http://www.idsa.in/idsacomments/rise-of-terrorism-inafrica_rberi_130417. Accessed: 1 October 2017; FOX NEWS. Al-Shabab fighters attack African Union convoy in southern Somalia, killing at least 8, 30 July 2017, [online]. Available at: http://www.foxnews.com/world/2017/07/30/al-shabab-fighters-attack-africanunion-convoy-in-southern-somalia-killing-at-least-8.html. Accessed: 1 October 2017.

5 AL JAZEERA. Kenya: Nine beheaded in suspected al-Shabab attack, 9 July 2017, [online]. Available at: http://www.aljazeera.com/news/2017/07/kenya-attack-170708103555604. html. Accessed: 1 October 2017.

6 TIME MAGAZINE. A Timeline of recent terror attacks in Europe, 20 December 2016, [online]. Available at: http://time.com/4607481/europe-terrorism-timeline-berlin-parisnice-brussels/. Accessed: 1 October 2017.

7 Ibid.

8 Ibid.

9 Ibid.

10 BBC NEWS. London Bridge attack: timeline of British terror attacks, 19 June 2017, [online]. Available at: http://www.bbc.com/news/uk-40013040. Accessed: 1 October 2017.

11 Ibid.

12 See art 25 of the United Nations Charter, 1945, which states that all members of the United Nations 'agree to carry out and accept the decisions of the Security Council in accordance with the present Charter.'

Published by Palacký University Olomouc, Czech Republic, 2018. ISSN (print): 1213-8770; ISSN (online): 2464-6601 
lation. ${ }^{13}$ Resolution 1624 of 2005 confirms the imperative to fight terrorism in all its forms and manifestations by all means in accordance with the UN Charter, condemns terrorism in all its forms and manifestations as unjustifiable and one of the most serious threats to peace and security, and affirms that states must take all necessary and appropriate measures in accordance with international law to protect the right to life. ${ }^{14}$

The US Central Intelligence Agency (CIA) reportedly began using 'enhanced interrogation techniques' after the terrorist attacks of 11 September 2001 (9/11). ${ }^{15}$ According to reports of the International Committee of the Red Cross (ICRC), interrogation sessions of detainees in Abu Ghraib and Guantanamo Bay included ill-treatments such as deprivation of sleep, food and water, exposure to extreme levels of heat and cold, stress and standing positions, waterboarding, sexual degradation and other cruel treatments which amounted to torture. ${ }^{16}$ Furthermore, while torture was banned by President Obama as an interrogation technique in 2009, President Trump has publicly supported the use of torture. ${ }^{17}$ In April 2018, Trump formally notified Congress of his nomination of Gina Haspel as the next director of the CIA. ${ }^{18} \mathrm{Ms}$ Haspel has been accused of playing a

13 Art 2(3) of S/RES 1373 (2001).

14 See S/RES 1624 (2005) (Counter-Terrorism Implementation Task Force).

15 ICRC. Report on the Treatment of Fourteen 'High Value Detainees' in CIA Custody, 2007, [online]. Available at: http://assets.nybooks.com/media/doc/2010/04/22/icrc-report.pdf. Accessed: 7 October 2017, p. 12; ICRC. Report of the International Committee of the Red Cross (ICRC) on the Treatment by the Coalition Forces of Prisoners of War and Other Protected Persons by the Geneva Conventions in Iraq During Arrest, Internment and Interrogation, 2004, [online]. Available at: http://www.derechos.org/nizkor/us/doc/icrc-prisonerreport-feb-2004.pdf. Accessed: 7 October 2012, p. 8; BUSINESS INSIDER. These Are The 13 'Enhanced Interrogation Techniques' the CIA Used On Detainees, 10 December 2014, [online]. Available at: http://www.businessinsider.com/the-13-enhanced-interrogationtechniques-the-cia-used-on-detainees-2014-12?IR=T. Accessed: 30 June 2018.

16 Ibid.

17 BBC NEWS. Donald Trump says he believes waterboarding works, 26 January 2017, [online]. Available at: https://www.bbc.com/news/world-us-canada-38753000. Accessed: 16 June 2018. BUSINESS INSIDER. Trump says torture absolutely works, 25 June 2017, [online]. Available at: www.businessinsider.com/trump-says-torture-absolutelyworks-2017-1. Accessed: 16 June 2018. See further FARMER, John J Jr., NEAFSEY, Edward M. Trump and the Law on Torture, 1 March 2018, [online]. Available at: https://www. lawfareblog.com/trump-and-law-torture. Accessed: 16 June 2018. For arguments of US politicians supporting the use of torture, see: Transcript of US Joint Congressional hearing. Extraordinary Rendition in US Counterterrorism Policy: The Impact on Transatlantic Relations. Subcommittee on International Organizations, Human Rights and Oversight and Subcommittee on Europe, 17 April 2007, [online]. Available at: http://foreignaffairs. house.gov/hearing_notice.asp?id=803. Accessed: 1 June 2018.

18 Public Broadcasting Service. Trump formally nominates Gina Haspel to be next CIA director, 17 April 2018, [online]. Available at https://www.pbs.org/newshour/politics/trumpformally-nominates-gina-haspel-to-be-next-cia-director. Accessed: 16 June 2018.

Published by Palacký University Olomouc, Czech Republic, 2018.

ISSN (print): 1213-8770; ISSN (online): 2464-6601 
role in the past torture of terrorist suspects by the CIA (including waterboarding and sleep deprivation). ${ }^{19}$

The use of torture during counter-terrorism measures remains controversial. On the one hand, certain states have advanced arguments in favour of derogating from the prohibition of torture in the fight against terrorism, and these arguments have found some support from scholars. ${ }^{20}$ On the other hand, there is a strong call for counter-terrorism measures to comply with states' obligations under international law, including the prohibition of torture. ${ }^{21}$ In light of this, the

19 SHUGERMAN, Emily. Gina Haspel: Who is the woman Donald Trump wants to take over the CIA? 11 May 2018, [online]. Available at: https://www.independent.co.uk/news/world/ americas/us-politics/gina-haspel-cia-director-donald-trump-nominated-mike-pompeorex-tillerson-a8346556.html. Accessed: 16 June 2018. While in her Senate committee hearing for the appointment as director of the CIA, Ms Haspel vowed to 'never, ever' restart the controversial CIA interrogation programme, she refused to call the methods the CIA had used 'immoral'. She stated that the CIA had done exceptional work in the aftermath of 9/11, but should be held to a 'stricter moral standard' now.

20 POSNER, Richard. Torture, Terrorism, and Interrogation. In LEVINSON, Stanford (ed). Torture: A Collection. Oxford: Oxford University Press, 2004, p. 294 (arguing that 'there is such a thing as a lesser wrong committed to avoid a greater one'); DERSHOWITZ, Alan. Tortured Reasoning. In LEVINSON (id.), p. 266 (arguing that torture is being used in the war on terrorism and that it is better for the rule of law to have such practices inside rather than outside the legal system); DERSHOWITZ, Alan. The Torture Warrant: a Response to Professor Strauss. New York Law School Law Review, 2003, vol. 48, p. 275; GERT, Bernard. Justifying Violence. The Journal of Philosophy, 1969, vol. 66, p. 623 (expressing the view that, while all killing and torturing for pleasure or profit is clearly immoral, 'killing and torturing to prevent greater killing and torturing may sometimes be allowed by public reason'). See further THE GUARDIAN. Torture Techniques endorsed by the Bush Administration, 17 April 2009, [online]. Available at: https://www.theguardian.com/ world/2009/apr/17/torture-methods-interrogation-george-bush-approved. Accessed: 12 August 2017, stating that torture and coercion were openly sanctioned as tools of interrogation at the highest levels of the Bush administration; THE NEW ZEALAND HERALD. Donald Trump May be Seeking to Reinstate Torture Methods for Detained Terrorist Suspects, 26 January 2017, [online]. Available at: https://www.nzherald.co.nz/world/news/ article.cfm?c_id=2\&objectid=11789393. Accessed: 12 August 2017. BBC NEWS. Israel Admits Torture, 9 February 2000, [online]. Available at: http://news.bbc.co.uk/2/hi/middle_east/637293.stm. Accessed: 12 August 2017.

21 OECHMICHEN, Anna. Terrorism and Anti-Terrorism legislation: The Terrorised Legislator? Doctoral Thesis, Leiden University, 2009, pp. 338-342. Available at: http://hdl.handle. net/1887/13852. Accessed: 1 July 2017. Oechmichen is of the view that the preservation of human rights is vital to prevent terrorism and that diminishing the rights of civilians ultimately destroys the faith of the people in the state. This, in turn, undermines the power of the state, and exacerbates, rather than diminishes, terrorist action. Amnesty International. Torture in 2014: 30 Years of Broken Promises, 5 December 2014, [online]. Available at: https://www.amnestyusa.org/sites/default/files/act400042014en.pdf. Accessed: 2 April 2016; MACMASTER, Neil. Torture: From Algiers to Abu Ghraib. Race and Class, 2004, vol. 46(2), p. 12 ('historically, whenever states started on the slippery slope of enabling a restricted or "controlled" use of duress, this inevitably deteriorated into a monstrous system of brutality'). See further Report of the Special Rapporteur on Torture and Other Cruel, Inhuman or Degrading Treatment or Punishment, Nils Melzer, appointed by UNHRC

Published by Palacký University Olomouc, Czech Republic, 2018.

ISSN (print): 1213-8770; ISSN (online): 2464-6601 
question arises whether the importance of the fight against terrorism might permit states to use all necessary means, even if these means infringing upon other norms which protect fundamental human rights and values of the international community.

This article will firstly consider state practice with regards to which acts constitute torture under the Convention Against Torture (CAT), specifically the interpretation of 'severe pain and suffering' as set out in the definition of torture in the CAT. Secondly, it will consider whether a limitation of the prohibition of torture is possible in the fight against terrorism. In this regard, section 2 will provide an overview of the development of a definition of torture under international law. Section 3 will consider whether the element of severe pain and suffering is required for an act to constitute torture. ${ }^{22}$ Finally, section 4 will evaluate whether any limitation of the prohibition of torture is possible in the fight against terrorism.

\section{The Definition of Torture under International Law}

Before the CAT came into force in 1987, there was no treaty definition of torture and / or cruel, inhuman or degrading treatment or punishment, although this conduct was prohibited under various regional and international treaties. These treaties provided that no-one shall be subjected to torture or to inhuman or degrading treatment or punishment, and that no derogation from the prohibition of torture is permitted, even in times of public emergency which threatens the life of the nation. ${ }^{23}$ The Inter-American Convention to Prevent and

resolution 1985/33, A/HRC/34/54, 14 February 2017, Yearbook of the International Law Commission II para 14: ' $\mathrm{t}$ ] he Special Rapporteur observes with alarm that, since the turn of the century, the rise of transnational terrorism, organized crime and other actual or perceived threats has given way to an increasing tolerance of violent political narratives and popular beliefs that not only trivialize torture and other cruel, inhuman or degrading treatment or punishment, but even promote and incite their use in the name of national security and the fight against terrorism.'

22 Ibid. For a discussion of the other elements of the definition of torture in the CAT, namely intent, purpose and state involvement, see DE BEER, Aniel. Peremptory norms of General International law (Jus Cogens) and the Prohibition of Terrorism. Unpublished doctoral thesis, 2018, chapter 4, on file with author.

23 See, for example, the European Convention for the Protection of Human Rights and Fundamental Freedoms, 1950. Art 3 provides that 'no-one shall be subjected to torture or to inhuman or degrading treatment or punishment.' In terms of art 15(2), in dealing with permissible derogations in times of public emergency, no derogation from the prohibition of torture is allowed. See further the International Covenant on Civil and Political Rights, 1966 (ICCPR); the American Convention of Human Rights, 1969 (ACHR); and the African Charter on Human and Peoples' Rights, 1981 (Banjul Charter). In terms of article 7 of the ICCPR, '[n]o one shall be subjected to torture or to cruel, inhuman or degrading treatment or punishment. In particular, no one shall be subjected without his/[her] free consent to medical or scientific experimentation.' Article 4(2) of the ICCPR provides that no derogation from the prohibition of torture is permitted. This applies even ' $[\mathrm{i}] \mathrm{n}$ times

Published by Palacký University Olomouc, Czech Republic, 2018.

ISSN (print): 1213-8770; ISSN (online): 2464-6601 
Punish Torture (IACPPT) of 1985 confirmed that no derogation is allowed in times of public emergency, and added that ' $[n]$ either the dangerous character of the detainee or prisoner, nor the lack of security of the prison establishment or penitentiary shall justify torture. ${ }^{24}$ The African Charter on Human and Peoples' Rights (Banjul Charter) also guaranteed the right of every individual to human dignity, and listed torture and cruel, inhuman or degrading punishment and treatment as examples of a form of exploitation and degradation. ${ }^{25}$ This illustrated a strong link between torture and the infringement upon human dignity (e.g. by using the word 'degradation'), and it seemed to imply that torture and cruel, inhuman or degrading punishment are regarded as particularly severe forms of exploitation and degradation, in the same category as slavery.

The first attempt to define torture in an international instrument was in 1975, when the United Nations General Assembly (UNGA) adopted the Declaration on the Protection of All Persons from Being Subjected to Torture or Other Cruel, Inhuman or Degrading Treatment or Punishment (the Declaration). ${ }^{26}$ In terms of the Declaration:

1 ...torture means any act by which severe pain or suffering, whether physical or mental, is intentionally inflicted by or at the instigation of a public official on a person for such purposes as obtaining from him or a third person information or confession, punishing him for an act he has committed or is suspected of having committed, or intimidating him or other persons. It does not include pain or suffering arising only from, inherent in or incidental to, lawful sanctions to the extent consistent with Standard Minimum Rules for the Treatment of Prisoners.

2. Torture constitutes an aggravated or deliberate form of cruel, inhuman or degrading treatment or punishment. ${ }^{27}$

As the Declaration was a non-binding instrument, the UNGA agreed in 1977 that work on a binding treaty prohibiting torture should commence. Finalising a binding treaty proved far more timeous than was the case with the Declaration - the CAT was only adopted by the UNGA in 1984 and entered into force in 1987, more than ten years after the Declaration. ${ }^{28}$ The definition of torture in the CAT adopted many elements of the Declaration, and, as at June 2017, it has

of public emergency which threatens the life of the nation.... See further Art 5(2) of the ACHR.

24 Art 5 of the Inter-American Convention to Prevent and Punish Torture, 1985.

25 Art 5 of the Banjul Charter (n 23 above) states that 'every individual shall have the right to the respect of the dignity inherent in a human being and to the recognition of his legal status. All forms of exploitation and degradation of man particularly slavery, slave trade, torture, cruel, inhuman or degrading punishment and treatment shall be prohibited.'

26 Arts $1 \& 2$ of the Declaration on the Protection of All Persons from Being Subjected to Torture or Other Cruel, Inhuman or Degrading Treatment or Punishment, 1975.

27 Ibid.

28 Convention against Torture and Other Cruel, Inhuman or Degrading Treatment or Punishment, 1984.

Published by Palacký University Olomouc, Czech Republic, 2018.

ISSN (print): 1213-8770; ISSN (online): 2464-6601 
been ratified or acceded to by 161 states. ${ }^{29}$ It defines torture for the purposes of the CAT as:

any act by which severe pain or suffering, whether physical or mental, is intentionally inflicted by or at the instigation of a public official on a person for such purposes as obtaining from him or a third person information or a confession, punishing him for an act he or a third person has committed or is suspected of having committed, or intimidating or coercing him or a third person or for any reason based on discrimination of any kind, when such pain or suffering is inflicted by or at the instigation of or with the consent or acquiescence of a public official or other person acting in an official capacity. It does not include pain or suffering arising only from, inherent in or incidental to lawful sanctions.

Although at first glance the definition of torture in the CAT seems similar to the definition in the Declaration, the CAT amended the scope of the definition of torture in various ways. ${ }^{30}$ Important for purposes of the present discussion,

29 United Nations Treaty Ratifications. [online]. Available at: https://treaties.un.org/Pages/ ViewDetails.aspx?src=IND\&mtdsg_no=IV-9\&chapter=4\&lang=en. Accessed: 17 June 2018. The Convention has been ratified or acceded to by the following states: Afghanistan, Albania, Algeria, Antigua and Barbuda, Argentina, Armenia, Australia, Austria, Azerbaijan, Bahrain, Bangladesh, Belarus, Belgium, Belize, Benin, Bolivia, Bosnia and Herzegovina, Botswana, Brazil, Bulgaria, Burkina Faso, Burundi, Cambodia, Cameroon, Canada, Cape Verde, Chad, Chile, China, Colombia, Congo, Costa Rica, Côte d'Ivoire, Croatia, Cuba, Cyprus, Czech Republic, Democratic Republic of the Congo, Denmark, Djibouti, Ecuador, Egypt, Equatorial Guinea, El Salvador, Estonia, Ethiopia, Finland, France, Gabon, Georgia, Germany, Ghana, Greece, Guatemala, Guinea, Guyana, The Holy See, Honduras, Hungary, Iceland, Indonesia, Ireland, Israel, Italy, Japan, Jordan, Kazakhstan, Kenya, Kuwait, Kyrgyzstan, Latvia, Lebanon, Lesotho, Liberia, Libya, Liechtenstein, Lithuania, Luxembourg, Malawi, Maldives, Mali, Malta, Mauritius, Mauritania, Mexico, Moldova, Monaco, Mongolia, Morocco, Mozambique, Namibia, Nepal, Netherlands, New Zealand, Niger, Nigeria, Norway, Panama, Paraguay, Peru, Philippines, Poland, Portugal, Qatar, Republic of Korea, Romania, Russian Federation, Saint Vincent and the Grenadines, Saudi Arabia, Senegal, Serbia and Montenegro, Seychelles, Sierra Leone, Slovak Republic, Slovenia, Somalia, South Africa, Spain, Sri Lanka, Swaziland, Sweden, Switzerland, Syrian Arab Republic, Tajikistan, Timor Leste, the former Yugoslav Republic of Macedonia, Togo, Tunisia, Turkey, Turkmenistan, Uganda, Ukraine, the United Kingdom, the United States, Uruguay, Uzbekistan, Venezuela, Yemen and Zambia.

30 Art 1 of the CAT (n 28 above). In terms of the CAT, torture includes an act intentionally inflicting severe pain or suffering for the purpose of punishing a person for an act that a third person has committed or is suspected of having committed. Furthermore, a torturous act can be committed by coercion of a person, and the purpose of the torture includes torture for any reason based on discrimination of any kind. In the CAT definition, the wording that torture excludes pain or suffering arising only from, inherent in or incidental to lawful sanctions to the extent consistent with Standard Minimum Rules for the Treatment of Prisoners, was deleted. See Report of the Working Group on a Draft Convention against Torture and Other Cruel, Inhuman or Degrading Treatment or Punishment E/CN4/L1470, 12 March 1979, E/CN4/L1470, Agenda item 10(a), para 21. See further LIPMAN, Matthew. The Development and Drafting of the United Nations Convention Against Torture and Other Cruel Inhuman or Degrading Treatment or Punishment. Boston College International and Comparative Law Review, 1994, vol. 17, pp. 314-315.

Published by Palacký University Olomouc, Czech Republic, 2018.

ISSN (print): 1213-8770; ISSN (online): 2464-6601 
the CAT omitted the paragraph stating that torture constitutes an aggravated or deliberate form of cruel, inhuman or degrading treatment or punishment. ${ }^{31}$ This was possibly the first signal of a move away from the focus on the degree of torture constituting either torture or cruel, inhuman or degrading treatment or punishment. The CAT did not attempt to define cruel, inhuman or degrading treatment or punishment and left it to signatory states to prevent acts of cruel, inhuman or degrading treatment or punishment in their territories. ${ }^{32}$ Article 16 of the CAT required that torture must be defined as a specific crime by states in their domestic legislation. Today, torture is widely prohibited in various regional conventions and the domestic legislation of states. ${ }^{33}$ Further, in terms of the definition of torture in the CAT, the four elements of torture are: severe pain or suffering; intent; purpose; and state involvement. ${ }^{34}$ This article will focus on whether conduct must constitute severe pain or suffering, as stated in article 1 of

31 Art 1 of the CAT (id).

32 Signatory states are obligated to report every four years to the Committee on their activities under the Convention.

33 Art 16 of the CAT further states that any definition of torture in legislation must be consistent with the definition set out in Art 1 of the CAT, and should incorporate the offences of cruel, inhuman or degrading treatment or punishment. Art 46 of the Constitution of the Bolivarian Republic of Venezuela, 1999 states that 'Everyone is entitled to respect for his or her physical, mental and moral integrity, therefore: (1) No person shall be subjected to penalties, torture, cruelty, inhuman or degrading treatment...'; see further art 182 of the Venezuela Penal Code, 2000; art 23 of the Constitution of Tunisia, 2014 'The state protects human dignity and physical integrity, and prohibits all types of moral and physical torture'; art 12 of the Constitution of Cameroon, 1972; Law No. 96-06 of 18 January 1996; art 12(1)(d) \& (e) of the Constitution of the Republic of South Africa, 1996; arts 16 \& 61(2) of the Constitution of the Democratic Republic of the Congo (DRC), 2005; art 101bis of the Criminal Code of the DRC, 2011; arts 25(a) \& 29 of the Constitution of Kenya, 2010; arts 8(2)(b) of the Constitution of Namibia, 1990; arts 24 \& 44 of the Constitution of the Republic of Uganda, 1995; art 2, 3 \& 4 of the Uganda Prevention and Prohibition of Torture Act, 2012; art 132(a) of the Sudan Constitution, 2005; art 2 of the Kenya National Police Service Act of 2011; art 51 of the Kenya National Intelligence Service Act 28 of 2012; arts 94-95 of the Turkish Penal Code, 2004; art 2(24)(h) of the Constitution of Peru, 1993; art 12 of the Constitution of Colombia, 1991; art 178 of the Columbia Penal Code Law no 599 of 2000; art 209-A of the Honduras Criminal Code (approved by decree 144-83), 1983; art 14(2) of the Constitution of the Islamic Republic of Pakistan, 1973 ('No person shall be subjected to torture for the purpose of extracting evidence'); art 53(2) of the Constitution of Syrian Arabic Republic, 2012; sec 269.1 of the Canadian Criminal Code, 1985; art 40 of the Constitution of the Republic of Poland, 1997 ('No one may be subjected to torture or cruel, inhuman, or degrading treatment or punishment'); art 7(2) of the Constitution of Greece, 1975 (as amended); art 21(2) of the Constitution of the Russian Federation, 1993; art 117 of the Criminal Code of the Russian Federation no 63-Fz of 13 June 1996; art 9(2) of the Criminal-Procedural Code of the Russian Federation No. 174-Fz of 18 December 2001; art 126 of the Constitution of Sri Lanka, 1978; art 2 of the Arabian Law of Criminal Procedure of 16 October 2001; art 3 of the South African Prevention of Combating and Torture of Persons Act, 2013.

34 Interim report of the Special Rapporteur on Torture and Other Cruel, Inhuman or Degrading Treatment or Punishment, Manfred Nowak, 28 July 2008, A63/175, para 46.

Published by Palacký University Olomouc, Czech Republic, 2018.

ISSN (print): 1213-8770; ISSN (online): 2464-6601 
the CAT to qualify as torture prohibited under international law. In other words, does state practice subsequent to the adoption of the CAT support this requirement as an element of conduct constituting torture under this convention? ${ }^{35}$ After this enquiry, it will then be evaluated whether any limitation of the prohibition of torture, for example the use of 'less severe' methods, is possible in the fight against terrorism.

\section{Severe pain and suffering as an element of torture}

The reference to 'severe pain and suffering' as an element of the definition of torture features in both the Declaration and the CAT. While the Declaration also refers to the degree of the torture involved, stating that torture is an aggravated or deliberate form of cruel, inhuman or degrading treatment or punishment, the CAT omits that reference. The question therefore arises as to whether severity is a requirement for pain and suffering to constitute torture and, closely related to this, whether there is an element of 'aggravation' or 'deliberation' required to elevate cruel, inhuman or degrading treatment or punishment to torture. This is important as it may be argued that certain conduct, for example subjecting terrorist subjects to wall-standing or hooding used as part of counter-terrorism measures, is not 'severe' enough to constitute torture.

With regards to domestic legislation, although pain and suffering in some form is included in all national legislation reviewed, legislation differs with regard to the severity element. Some national legislation includes the severity element: in South Africa, Kenya and Uganda, national legislation requires severe pain and suffering to constitute torture. ${ }^{36}$ In Cameroon, the Criminal Code

35 See draft conclusion 7 of the International Law Commission Report on the work of the 66th session, 5 May - 6 June 2014 and 7 July - 8 August 2014, A/69/10, Supplement no 10 , p. 240 , in terms of which state practice includes 'the conduct of States "on the ground", diplomatic acts and correspondence, legislative acts, judgements of national courts, official publications in the field of international law, statements on behalf of States concerning codification efforts, practice in connection with treaties and acts in connection with resolutions of organs of international organizations and conferences.' See article 31(3)(b) of the Vienna Convention on the Law of Treaties, 1969, which provides that 'any subsequent practice in the application of the treaty which establishes the agreement of the parties regarding its interpretation' can be taken into account for the purposes of treaty interpretation.

36 In South Africa, art 3 of the Prevention of Combating and Torture of Persons Act 1 of 2013 defines torture as 'any act or omission, by which severe pain or suffering, whether physical or mental, is intentionally inflicted on a person...' In Kenya, sec 51(4) of the National Intelligence Service Act (note 33 above) similarly defines torture as 'any act by which severe pain or suffering, whether physical or mental, is intentionally inflicted on a person...' Further, in Kenya, sec 2 of the National Police Service Act and sec 51 of the National Intelligence Service Act (note 33 above) provides that '[c]ruel, inhuman and degrading treatment or punishment means 'a deliberate and aggravated treatment or punishment not amounting to torture, inflicted by a person in authority or the agent of the person in authority against a person under his custody, causing suffering, gross humiliation or debasement to the per-

Published by Palacký University Olomouc, Czech Republic, 2018.

ISSN (print): 1213-8770; ISSN (online): 2464-6601 
requires pain or severe suffering for an act to constitute torture (thus restricting severity to the suffering but not the pain). ${ }^{37}$ The Democratic Republic of the Congo's Law Criminalising Torture requires intent and severe pain or suffering, whether physical or mental. ${ }^{38}$ Canadian legislation refers to the severity of the pain and suffering, defining torture as 'any act or omission by which severe pain or suffering' occurs. ${ }^{39}$ Latvia requires that the acts must cause 'particular' pain or suffering to victims while Greece and Luxembourg use the word 'acute' instead of 'severe. ${ }^{\prime 0}$ In Uganda, severe pain and suffering includes the intentional or threatened infliction of physical pain or suffering, the administration or threatened application of mind-altering substances 'or other procedures calculated to disrupt profoundly the senses or the personality', as well as the threat of imminent death. ${ }^{41}$ Further, the definition includes not only such threats to the victim, but also the threat that another person will suffer this fate. Accordingly, the definition is wide and does not seem to require actual physical pain and suffering.

In Algeria, the definition of torture requires severe pain and suffering. ${ }^{42}$ In Armenia, the Criminal Code defines torture as causing strong pain or physical or mental suffering and distinguishes between degrees of torture. ${ }^{43}$ In Sri Lanka, an act which causes severe pain, whether physical or mental, constitutes torture, but the reference to suffering is omitted. ${ }^{44}$ In the Philippines, torture refers to

son. In Uganda, art 2(1) of the Prevention and Prohibition of Torture Act (note 33 above) defines torture as 'any act or omission, by which severe pain or suffering whether physical or mental, is intentionally inflicted on a person...'

37 Art 132(5) of the Cameroon Penal Code, 1967 (as amended) defines torture to mean: '[a]ny act by which severe pain or suffering, whether physical or mental, is intentionally inflicted...'

38 See art 48bis of Law no 11/008 of 9 July 2011 amending the Criminal Code of the DRC, 2004.

39 See art 269.1(2) of the Canada Criminal Code C-46, 1985.

40 Consideration of Reports Submitted by State Parties under Article 19 of the Convention, Latvia, UN Doc CAT/C/21/Add.4 6. [online]. Available at www.unhchr.ch/tbs/doc.nsf/ (Symbol)/CAT.C. 21.Add.4.En?OpenDocument. Accessed: 6 May 2017; Consideration of Reports Submitted by State Parties under Article 19 of the Convention, Greece, UN Doc CAT/C/61/Add.2 230. [online]. Available at: www.unhchr.ch/tbs/doc.nsf/ (Symbol)/ CAT.C.61.Add.1.En?Opendocument. Accessed: 6 May 2017; Consideration of Reports Submitted by State Parties under Article 19 of the Convention, Luxembourg, UN Doc CAT/C/ SR.517 [online]. Available at: www.unhchr.ch/tbs/doc.nsf/(Symbol)/4870d067077d49 bac1256a26004c2298?Open document. Accessed: 1 May 2017.

41 Art 2(1) of the Prevention and Prohibition of Torture Act (note 33 above).

42 Art 263bis of the Penal Code of Algeria, 1966: 'Est entendu par torture tout acte par lequel une douleur ou des souffrances aiguës, physiques ou mentales sont intentionnellement infligées à une personne quelqu'en soit le mobile.' (Torture is understood to mean any act by which severe pain or suffering, whether physical or mental, is intentionally inflicted on any person, whatever the motive) (own translation).

43 Art 11(2) of the Armenia Criminal Code, 2003.

44 Art 12 of the Sri Lanka Convention against Torture and Other Cruel, Inhuman or Degrading Treatment or Punishment Act, 1994 defines torture as 'any act which causes severe pain, whether physical or mental, to any other person...'

Published by Palacký University Olomouc, Czech Republic, 2018.

ISSN (print): 1213-8770; ISSN (online): 2464-6601 
an act by which severe pain and suffering, whether physical or mental, is intentionally inflicted..$^{45}$ The US, as a condition for ratifying the CAT, submitted formal understandings including a more precise definition of mental torture, and argued that only extreme forms of pain or suffering amount to torture. ${ }^{46}$

In Mexico, the definition of torture refers to severe pain and suffering, whether physical or mental. ${ }^{47}$ In the UK, torture is prohibited in the Criminal Justice Act which refers to severe pain and suffering. ${ }^{48}$ In France, the Ministry of Justice circular of 14 May 1993 on the Criminal Code that came into force on 1 March 1994 supports the definition in article 1 of the CAT as well as the requirement of severity. ${ }^{49}$ Croatia requires physical or mental pain or severe physical or mental suffering to constitute torture. ${ }^{50}$ Egyptian law imposes no requirements with regard to the degree or extent of pain or suffering. ${ }^{51}$ The Greek Penal Code refers to 'acute' instead of severe, and torture is broadly defined to include any systematic infliction of acute physical pain or physical exhaustion endangering

45 Art 3(a) of the Philippines Anti-Torture Act, 2009.

46 See 18 US Code $\$ 2340$ (2004). See further Convention against Torture and Other Cruel, Inhuman or Degrading Treatment or Punishment: Reservations, Understandings and Declarations made by the United States of America. [online]. Available at: http://www.unhchr. ch/tbs/doc.nsf/0/5d7ce66547377b1f802567fd0056b533?Open Document. Accessed: 12 August 2017. The US ratified the CAT with reservations. It stated that mental pain or suffering refers to prolonged mental harm caused by or resulting from: (1) the intentional infliction or threatened infliction of severe physical pain or suffering; (2) the administration or application, or threatened administration or application, of mind altering substances or other procedures calculated to disrupt profoundly the senses or the personality; (3) the threat of imminent death; or (4) the threat that another person will imminently be subjected to death, severe physical pain or suffering, or the administration or application of mind altering substances or other procedures calculated to disrupt profoundly the senses or personality.

47 See Mexico's Federal Act on the Prevention and Punishment of Torture, 1991.

48 See art 134 of the UK Criminal Justice Act, 2017.

49 See ICRC. France: Practice Relating to Rule 90. Torture and Cruel, Inhuman or Degrading Treatment. Available at: https://ihl-databases.icrc.org/customary-ihl/eng/docs/v2_cou_ fr_rule90. Accessed 1 July 2018. See statement by France, referring to the wording of the circular that ' $\mathrm{g}$ ] enerally speaking, there may be qualified as torture within the meaning of article 1 of the Convention against Torture and Other Cruel, Inhuman or Degrading Treatment or Punishment, adopted at New York on 10 December 1984, 'any act whereby severe pain or suffering, whether physical or mental, is intentionally inflicted on a person.'

50 Art 176 of the Criminal Code of Croatia 111 of 15 July 2003. See further Consideration of reports submitted by state parties under article 19 of the Convention, Croatia, UN Doc CAT/C/54/Add3 12, 6-7 May 2004, [online]. Available at: http://www.unhchr.ch/tbs/doc. nsf/(Symbol)/CATC54Add3En?OpenDocument. Accessed: 17 June 2018.

51 Consideration of reports submitted by state parties under article 19 of the Convention, Egypt, UN Doc CAT/C/34/Add.11, 28 January 1999, [online]. Available at: www.unhchr. ch/tbs/doc.nsf/(Symbol)/CATC34.Add.11.En?OpenDocument. Accessed: 1 May 2017. Egypt states that: ' $\mathrm{t}$ ] he provisions of Egyptian law are broader and more general than those of the Convention, since article 1 of the latter defines torture as any act by which severe pain or suffering is inflicted, whereas Egyptian law imposes no prerequisites concerning the degree or extent of pain or suffering.'

Published by Palacký University Olomouc, Czech Republic, 2018.

ISSN (print): 1213-8770; ISSN (online): 2464-6601 
the health of a person, mental suffering and any illegal use of chemical, drugs or other natural or artificial means aiming at bending the victim's will. ${ }^{52}$ Under the Iraqi Penal Code, torture includes the use of force or menaces, but is not defined in terms of pain and suffering. ${ }^{53}$

The Turkish Penal Code contains a comprehensive reference to torture. It devotes part 3 of its legislation to 'Torture and Torment. ${ }^{54}$ While it does not require severity of an act to constitute torture, it provides for a range of acts ranging from torture to torment, implying separation by degree. ${ }^{55}$ It criminalises any act incompatible with human dignity which causes a person to suffer physically or mentally or affects the person's ability to act of his own will. ${ }^{56}$ The element of severity appears from a section that specifically provides for aggravated torture on account of its consequences, namely where the torture causes permanent physical or mental impairment, death or the loss of a child where the victim is a pregnant woman. ${ }^{57}$ It further prohibits 'torment' with harsher penalties should such torment be against a child, a person who is physically or mentally incapable of defending himself, a pregnant woman or the family of the perpetrator. 'Torment' is, however, not defined. ${ }^{58}$

Kazakhstan's Penal Code does not contain the severity requirement although it refers to torture as the infliction of physical and mental suffering by means of systematic harassment or other violent actions. ${ }^{59}$ The Russian Criminal Code does not require that pain or suffering be severe. ${ }^{60}$ That said, its Criminal Code refers to the infliction of physical or mental suffering by means of systematic

52 Consideration of Reports Submitted by State Parties under Article 19 of the Convention, Greece, UN Doc CAT/C/61/Add.2, 16 February 2004, [online], p. 230. Available at: www. unhchr.ch/tbs/doc.nsf/ (Symbol)/CAT.C.61.Add.1.En?Opendocument. Accessed: 6 May 2017.

53 Iraq Penal Code, 1969.

54 Art 94(1) of the Turkish Penal Code, 2004 provides that, "[a] public officer who performs any act towards a person that is incompatible with human dignity, and which causes that person to suffer physically or mentally, or affects the person's capacity to perceive or his ability to act of his own will or insults them shall be sentenced to a penalty of imprisonment for a term of three to twelve years. Art 96(1) provides that '[a]ny person who performs any act which results in the torment of another person shall be sentenced to a penalty of imprisonment for a term of two to five years; (2) [w] here the acts falling under the above paragraph are committed against inter alia: a child who cannot protect himself due to corporal or spiritual disability or a pregnant woman, a penalty of imprisonment for a term of three to eight years shall be imposed.'

55 Ibid.

56 Art 94(1) of the Turkish Penal Code (n 54 above).

57 Ibid.

58 Ibid.

59 Art 347-1 of the Kazakstan Criminal Code, Law no 167 of 16 July 1997 refers to torture as the 'deliberate causation of physical or psychic suffering.'

60 Art 117(1) of the Criminal Code of the Russian Federation (n 33 above) defines torture as the infliction of physical or mental suffering.

Published by Palacký University Olomouc, Czech Republic, 2018.

ISSN (print): 1213-8770; ISSN (online): 2464-6601 
beating or by any other violent actions in the section dealing with torture, which does seem to refer to a degree of severity. ${ }^{61}$ The German Constitution provides that a detained person 'may not be subjected to mental or physical ill-treatment. ${ }^{62}$ Accordingly, the national legislation of various states is inconsistent with regards to the severity element, but consistent in relation to the inclusion of a form of pain and suffering in the definition of torture. ${ }^{63}$

In national case law, the severity element was evident when deeming certain acts as torture. In the 1995 case of Xuncax v Gramajo, a US federal district court deemed a combination of blindfolding, repeated acts of rape, burning with cigarettes, beating, and lowering into a foul-smelling pit during interrogation by the Guatemalan military to be torture..$^{64}$ This is consistent with the US view discussed above that severity is a requirement for torture. As regards matters before the African Commission, the Commission found in the Abdel Hadi case that the treatment of persons with the aim of extracting confessions from the victims and as punishment for the killing of policemen, which ranged from 'severe beating with whips and sticks, doing the Arannabb Nut (rabbit jump), heavy beating with water hoses on all parts of their bodies, death threats, forcing them to kneel with their feet facing backwards in order to be beaten on their feet and asked to jump up immediately after, as well as other forms of ill-treatment' which resulted in serious physical injuries and psychological trauma, amounted to torture. ${ }^{65}$

The case law of regional treaty bodies, however, placed less emphasis on the requirement of severity and seemed to illustrate a move towards the prohibition of torture in the absence of physical violence (including the threat of violence and mental torture). In this regard, the practice of the Human Rights Committee (HRC) in deciding torture cases under the Optional Protocol to the ICCPR illustrates that the HRC did not distinguish clearly between torture and cruel, inhuman and degrading treatment or punishment or clarify when a torturous act would be regarded as severe. ${ }^{66}$ In the Estrella case, for example, the complainant, a pianist, was subjected to severe physical and psychological torture, including the threat that his hands would be cut off by an electric saw in an effort to force him to admit subversive activities ${ }^{67}$ The HRC found a contravention of the pro-

61 Ibid.

62 Sec 104(1) of the Basic Law for the Federal Republic of Germany, 1949.

63 For example South Africa, Kenya, Uganda, Cameroon, the DRC, Canada, Latvia, Greece, Luxemburg, Bahrain, Sri Lanka, Philippines, Algeria, Mexico, the US and the UK requires a degree of severity for an act to constitute torture. No severity is required in the definitions of torture of Egypt, Spain, Turkey, Kazakhstan, Bangladesh, Iraq, Brazil, Russia and Croatia.

64 Xuncax v Gramajo 886 FSupp (D Mass 1995) 162, 174, 178.

65 African Commission, Abdel Hadi, Ali Radi \& Others v Republic of Sudan, Communication 368/09 (5 November 2013) para 71.

66 See art 7 of the ICCPR (n 23 above).

67 Communication 74/1980, Miguel Angel Estrella v Uruguay, UNHR Committee, 17 July 1980, UN Doc Supp No 40 (A/38/40) 150 (1983) para 1.6.

Published by Palacký University Olomouc, Czech Republic, 2018. ISSN (print): 1213-8770; ISSN (online): 2464-6601 
hibition of torture and cruel, inhuman and degrading treatment or punishment under the ICCPR, as well as a contravention of the complainant's right to human dignity as he was detained under inhuman prison conditions during the first days of his detention. ${ }^{68}$ In the Cabreira case, on the other hand, despite detailed allegations of torture (including beatings, near-drownings and lack of food), the HRC found only a contravention of the complainant's right to human dignity. ${ }^{69}$ In the Bequio case the HRC found a violation of the prohibition of torture and cruel, inhuman and degrading treatment or punishment in the ICCPR, as well as a contravention of the complainant's right to human dignity, not on the basis of torture but on the basis that the complainant had 'not been treated in prison with humanity and with respect for the inherent dignity of the human person. ${ }^{30}$

Later decisions also took into account the personal circumstances of the relevant victim. For example, it would appear that in cases where there was evidence of severe torture or the victim was elderly and suffered from medical conditions, the HRC was more likely to use the word 'torture' in its decisions. In the Peñarrieta case the victim was in poor health and had a skull fracture which did not receive medical attention for some time. He was also subjected to severe torture, including physical beatings, electric shocks and immersion in water, and the torture was proven by medical certificates. ${ }^{71}$ The HRC stated in its decision that the victim had been subjected to 'torture and inhuman treatment."72

The decisions of the Committee against Torture, established to monitor the application of the CAT, have not dealt with the difference between torture and other forms of cruel, inhuman or degrading conduct or treatment, and the definitional threshold between the two forms of conduct remains as unclear as it was when the CAT was adopted. ${ }^{73}$ The Committee has, however, indicated support for a broad interpretation of what constitutes torture. In this regard, it noted

68 Estrella case (id.) para 10.

69 Communication 105/1981, Cabreira v Uruguay, UNHR Committee, 7 August 1981, UN Doc CCPR/C/OP/2 (1990) para 11.

70 Communication 88/1981, Bequio v Uruguay, UNHR Committee, 14 March 1981, UN Doc CCPR/C/OP/2 (1990), para 12.

71 Communication 176/1984, Lafuente Peñarrieta et al. v Bolivia, UNHR Committee, 2 November 1987, UN Doc CCPR/C/OP/2 201 (1990), paras 1.3, 10.4.

72 Lafuente Peñarrieta et al. (id.), para 16. See further Communication 110/1981, Acosta v Uruguay, UNHR Committee, 12 August 1981, UN Doc Supp no 40, A/39/40, 1984, para 14. In the Acosta matter, allegations were similarly of severe torture but were, to a great extent, unsubstantiated. The HRC found that the complainant was subjected to inhuman treatment but did not refer to torture in its finding.

73 See UN Committee Against Torture. General Comment No. 2: Implementation of Article 2 by States Parties. 24 January 2008, CAT/C/GC/2, [online]. Available at: http://www. refworld.org/docid/47ac78ce2.html. Accessed: 30 June 2018. Para 3 states that 'The obligations to prevent torture and other cruel, inhuman or degrading treatment or punishment (hereinafter "ill-treatment")... are indivisible, interdependent and interrelated. The obligation to prevent ill-treatment in practice overlaps with and is largely congruent with the obligation to prevent torture.' 
that, as mental torture is included within the definition of torture in the CAT, the threat of torture or mock executions may itself amount to psychological torture. ${ }^{74}$ With regard to psychological torture, where captured Taliban and al Qaida operatives were allegedly subjected to physical and psychological 'stress and duress' techniques, including being deprived of sleep for long periods, held blindfolded or hooded or bound in akward, painful positions, this would then arguably constitute torture. ${ }^{75}$

Early case law of the European Commission (EC) in deciding contraventions under the ECHR points to a tendency to distinguish torture from cruel, inhuman and degrading treatment or punishment by the degree of suffering involved. For example, in the Greek case in 1969 the EC considered the concept of torture and its relationship to the concept of inhuman treatment and degrading treatment. ${ }^{76}$ In its report, the EC described torture as 'an aggravated form of inhuman treatment."77 The EC, therefore, distinguished between torture and inhuman treatment on the basis of aggravation. Furthermore, in dealing with the deplorable conditions in Greek detention facilities where political prisoners were kept, the EC held that degrading treatment or punishment constitutes a category by itself requiring severe humiliation or coercion of a person to act against his or her own will or conscience. ${ }^{78}$

In other instances, the EC and the European Court of Human Rights (ECtHR) have characterised the same conduct as constituting either torture or cruel, inhuman and degrading treatment or punishment. In the case of Ireland $v$ United Kingdom, suspected terrorists were subjected to wall-standing, hooding, subjection to noise, deprivation of sleep and deprivation of food and drink. The EC was of the view that the combined use of these five techniques of interrogation constituted torture. ${ }^{79}$ The ECtHR, on the other hand, determined that, while the use of these techniques constituted inhuman and degrading treatment,

74 UN Committee against Torture, Report on Argentina, UN Doc A/45/44, 21 June 1990, para 154, [online]. Available at: https://digitallibrary.un.org/record/97924. Accessed: 30 June 2018.

75 Washington Post. US Decries Abuse but Defends Interrogations, 26 December 2000, [online]. Available at: https://www.washingtonpost.com/. Accessed: 16 June 2018.

76 The Greek Case Report of the Commission: Application no 3321/67-Denmark v Greece, Application no 3322/67-Norway v Greece, Application no 3323/67-Sweden v Greece, Application no 3344/67-Netherlands v. Greece (1970) EC 1 1; DANELIUS, Hans. Torture and Cruel, Inhuman or Degrading Treatment or Punishment. Nordic Journal of International Law, 1959, vol. 58, p. 180.

77 id., p. 186. The Court stated that '...the word "torture" is often used to describe inhuman treatment, which has a purpose, such as the obtaining of information or confessions, or the infliction of punishment, and it is generally an aggravated form of inhuman treatment. Treatment or punishment of an individual may further be said to be degrading if it grossly humiliates a person before others or drives him to act against his will or conscience.'

78 Ibid.

79 Ireland $\mathrm{v}$ the United Kingdom EC, Yearbook of European Convention on Human Rights, 1976, vol. 512, p. 489-491.

Published by Palacký University Olomouc, Czech Republic, 2018.

ISSN (print): 1213-8770; ISSN (online): 2464-6601 
the techniques 'did not occasion suffering of the particular intensity and cruelty implied by the word torture as so understood. ${ }^{80}$ The ECtHR seemed, thus, to follow the same line of thinking as the EC in the Greek case, distinguishing between torture and inhuman and degrading treatment on the basis of the degree of suffering involved. ${ }^{81}$

Selmouni $v$ France marked a departure from the previous thinking of the ECtHR discussed above. The complainant was arrested for drug trafficking and alleged that he was subjected to ill-treatment while in police custody, including assault, indecent assault and threats of violence. ${ }^{82}$ In order to determine whether a particular form of ill-treatment should be qualified as torture, the court was of the view that it must have regard to the distinction between torture and inhuman or degrading treatment as set out in article 3 of the ECHR. It noted that it remains to be established whether the pain or suffering inflicted on Mr Selmouni can be defined as 'severe' within the meaning of Article 1 of the CAT. The court, however, was of the view that this 'severity' is relative, and it depends on all the circumstances of the case, including the duration of the treatment, its physical or mental effects, the sex, age and state of health of the victim. ${ }^{83}$

The court stated that the CAT is a living instrument which must be interpreted in the light of present-day conditions. ${ }^{94}$ Accordingly, certain acts, which had in the past been classified as inhuman and degrading treatment and not

80 See Ireland v the United Kingdom, Application no 5310/71, ECHR, judgement, 18 January 1978, para 167: 'In order to determine whether the five techniques should also be qualified as torture, the Court must have regard to the distinction, embodied in Article 3 (art. 3), between this notion and that of inhuman or degrading treatment. In the Court's view, this distinction derives principally from a difference in the intensity of the suffering inflicted.' Although the five techniques, as applied in combination, undoubtedly amounted to inhuman and degrading treatment, although their object was the extraction of confessions, the naming of others and/or information and, although they were used systematically, they did not occasion suffering of the particular intensity and cruelty implied by the word torture as so understood. According to the Court, the notion of torture was characterised by "a special stigma" attaching to "deliberate inhuman treatment causing very serious and cruel suffering".

81 Ireland case (id.), pp. 60-63. In the Separate Opinion of Judge Zekia (dissenting), he did not share the view that extreme intensity of physical or mental suffering is a requisite for a case of ill-treatment to amount to 'torture' as contemplated in art 3 of the ECHR and that all the relevant circumstances should be considered. He advocated a more subjective definition taking into account 'the nature of ill-treatment inflicted, the means and methods employed, the repetition and duration of such treatment, the age, sex and health condition of the person exposed to it, the likelihood that such treatment might injure the physical, mental and psychological condition of the person exposed...'

82 Selmouni v France, Application no 25803(94), ECHR, 1 December 1977, paras 20, 24.

83 Id., para 100.

84 Id., para 101. Regarding the view that the CAT is a living instrument, the ECtHR referred to Tyrer v the United Kingdom, 25 April 1978, Series A no 26, p. 15 para 31; Soering v United Kingdom, Application 14038/88, ECHR, 7 July 1989, p. 40, para 91, sec 102; and Loizidou v Turkey, 23 March 1995, Series A, no 310, p. 26, sec 71.

Published by Palacký University Olomouc, Czech Republic, 2018.

ISSN (print): 1213-8770; ISSN (online): 2464-6601 
torture, could be classified differently in future. ${ }^{85}$ It noted that the increasingly high standard being required in the area of the protection of human rights and fundamental liberties 'inevitably requires greater firmness in assessing breaches of the fundamental values of democratic societies. ${ }^{\text {'6 }}$ It has been argued that the court was indicating that it may then consider the mixed physical and psychological pressures involved in the five interrogation techniques to which terrorist suspects were subjected in the Northern Ireland case, as torture.$^{87}$ Furthermore, in response to Israel's country report in 1997, the concluding observation of the Committee on Torture stated that the following methods of interrogation all constituted torture: restraining in very painful conditions; hooding; sounding of loud music or sleep deprivation for prolonged periods; threats, including death threats; violent shaking; and 'using cold air to chill.' ${ }^{38}$ In this regard, the InterAmerican Commission of human Rights (IACHR) has similarly supported a broad interpretation of the prohibition of torture and the right to humane treatment during anti-terrorist initiatives. ${ }^{89}$ This included a consideration of detention conditions of suspected terrorists and the treatment of persons in situations of particular vulnerability, including women, children and non-nationals, especially when considering conduct during interrogations of such persons by state agents. ${ }^{90}$ In the various cases before the IACHR, it made no reference to severity or aggravation being a requirement to constitute torture. ${ }^{91}$

In the case of Durant and Ugarte $v$ Peru decided by the IACtHR in 2000, the complainants were arbitrarily arrested and incarcerated on suspicion of participation in terrorist acts, and both were killed during a prison riot by the use of excessive force by Peruvian armed forces. ${ }^{92}$ The court was of the view that forced disappearance and the disproportionate and unjustified use of force alone are

85 Id., para 101.

86 Ibid.

87 A \& Others v Secretary of State for the Home Department (No 2), (2005) (HL)1 WLR 53, where Lord Bingham of Cornwall indicated that the techniques used in Ireland v UK might now be held to constitute torture under art 3 of the ECHR.

88 Committee against Torture, Consideration of Reports Submitted by States Parties Under Article 19 of the Convention: Conclusions and recommendations of the Committee Against Torture, UN Doc. A/52/44, 10 September 1997, [online]. Available at: https://unispal.un.org/DPA/DPR/unispal.nsf/0/CA3A3721CCF0729B05256545005095B0. Accessed: 30 June 2018.

89 Report of the Inter-American Commission on Human Rights Right to Humane Treatment, para 164, [online]. Available at: http://www.cidh.oas.org/Terrorism/Eng/part.f.htm\#_ ftn418. Accessed: 3 October 2017.

90 Loayza-Tamayo v Peru, IACtHR, 17 September 1997, Series C No 33, para 57.

91 See, e.g., Mejía v Peru, IACHR, 1 March 1996, OEA/SerL/V/II91 Doc 7 sec B, para 2. See further Morales v Guatemala Inter-American Commission of Human Rights, IAm Comm of HR (8 March 1998) Ser C No 37 134. The IACtHR held that torture includes the use of methods upon a person intended to obliterate the personality of the victim or to diminish his/her physical or mental capabilities, even if the methods do not cause physical pain or torture (tying, beating, etc).

92 Durand and Ugarte v Peru, IACHR, 16 August 2000, Ser C, No 68, para 59.

Published by Palacký University Olomouc, Czech Republic, 2018.

ISSN (print): 1213-8770; ISSN (online): 2464-6601 
insufficient for a finding of torture, cruel, inhumane, or degrading treatment. ${ }^{93}$ In his partially dissenting opinion, Judge De Roux Rengifo asserted that it may be concluded that the victims suffered severe mental and physical anguish between the time of the riot suppression efforts and the time of their deaths so as to amount to cruel, inhumane, or degrading treatment. ${ }^{94}$

From the evaluation above, it appears that the severity requirement may no longer be regarded by regional commissions and courts as an integral requirement for conduct complained of, to constitute torture. Furthermore, the practice of the EC and the ECtHR illustrate that the distinction between torture and cruel, inhuman or degrading treatment or punishment is disappearing, as conduct which used to constitute inhuman treatment may now constitute torture. Moreover, it is recognised that torture is relative to the personal circumstances of the victim concerned. The result of this is that certain conduct cannot be excluded from prohibited torture on the basis that it does not meet the severity threshold under the CAT. The second enquiry is whether the prohibition of torture can be limited during counter-terrorist measures, and this will be considered in section 4 below.

\section{The Prohibition of Torture and the Prohibition of Terrorism}

Torture remains widespread despite its official prohibition. ${ }^{95}$ After 9/11, it was alleged that the protection of human rights compromises the ability of states to respond to terrorism. Torturing suspected terrorists was suggested to be a legitimate tool which should be allowed in extreme cases to extrapolate important information from terrorist suspects, in particular where the torturing of one or more terrorists might save hundreds of lives. ${ }^{96}$ In this regard, both Israel and the US have infamously used questionable interrogation methods in their wars

93 Ibid.

94 Durand and Ugarte case (n 92 above) 191: see partially Dissenting Opinion of Judge De Roux Rengifo.

95 See Amnesty International Report (n 21 above); BELLAMY, Alex J. No pain, no gain? Torture and Ethics in the War on Terror. International Affairs, 2006, vol. 82(1), pp. 121-148; BUHA, Mark J. Rule Utilitarian and Deontologist Perspectives on Comparisons of Torture and Killing. Washington University Juridical Review, 2010, vol. 2, p. 304. See further EDGERTON, Robert B. The Worldwide Practice Of Torture. New York: Edwin Mellen Press Ltd, 2007; HATHAWAY, Oona. Do Human Rights Treaties Make a Difference? Yale Journal of International Law, 2002, p. 1935.

96 See FEIN, Helen. Human Rights and Wrongs: Slavery, Terror, Genocide. Colorado: Paradigm Publishers, 2007, pp. 63-76, noting that the French authorities have argued at length that employing torture in Algeria has led to successful counterterrorism efforts. For further discussion, see RODLEY, Nigel. The Prohibition of Torture: Absolute Means Absolute. Denver Journal of International Law \& Policy, 2006, vol. 34, pp. 145-160; Article 15-6 Investigation of the 800th Military Police Brigade - the Taguba Report: a Report prepared by Maj.Gen. AM Taguba on Alleged Abuse of Prisoners by Members of the 800th Military Police Brigade at the Abu Ghraib Prison, Baghdad. [online]. Available at: https://fas.org/ irp/agency/dod/taguba.pdf. Accessed: 16 April 2017.

Published by Palacký University Olomouc, Czech Republic, 2018.

ISSN (print): 1213-8770; ISSN (online): 2464-6601 
on terror. ${ }^{97}$ It was argued that there are 'very unpleasant but very real cases in which we are morally permitted - indeed morally compelled - to do terrible things. ${ }^{38}$ Related to this is the argument that leaders may violate morality in order to secure the good of the communities they protect. ${ }^{99}$

Certain question arise in this context. Firstly, can it be argued that the limitation of the human rights of one individual should be sacrificed for the good of the many, in the context of terrorist attacks threatening the life of a nation - in other words, a utilitarian argument? Secondly, if the prohibition of terrorism and the prohibition of torture are both norms of jus cogens which allow no derogation, is there a norm conflict when both norms are applied to the same situation, and can this be resolved through the limitation of one of the norms, namely the prohibition of torture?

\subsection{The utilitarian argument}

The utilitarian argument emphasises bringing about 'the greatest amount of good for the greatest number. ${ }^{100}$ The ticking time-bomb scenario will be used as an example of using this argument as support for limiting the prohibition of torture in the fight against terrorism. In this scenario, a terrorist has placed a bomb in a large city that will cause catastrophic loss of life. ${ }^{101}$ The terrorist is the only person who knows where the bomb is and how to defuse it. Can the prohibition of torture be limited in order to allow actions that would amount to torture in order to extract the information from the terrorist? Authors have argued that this is the kind of situation in which torture 'is not merely permissible but morally mandatory' and that, in this scenario, there is no reason not to torture the terrorist. ${ }^{102}$ Indeed, Dershowitz notes that, in this situation, where it concerns the violation of the rights of a single criminal individual to save the lives of thousands of innocent people, most people would agree that torture is allowed. ${ }^{103}$

97 GUR-ARYE, Miriam. Can the War against Terror Justify the Use of Force in Interrogations? Reflection in Light of the Israeli Experience in S LEVINSON (n 20 above).

98 KRAUTHAMMER, Charles. The Truth about Torture in LEVINSON (n 20 above).

99 See WALZER, Michael. Political Action: The Problem of Dirty Hands, in LEVINSON (n 20 above).

100 See the Stanford Encyclopaedia of Philosophy. The History of Utalitarianism, 27 March 2009 [online]. Available at: https://plato.stanford.edu/entries/utilitarianism-history/. Accessed: 24 June 2018.

101 KOLA, Fatima. Torture and Terrorism - a case study. Supplement UCL Jurisprudence Review, 2007, pp. 85, 97.

102 LEVIN, Michael. The Case for Torture, 1982 [online]. Available at: http://people.brandeis. edu/ teuber/torture.html. Accessed: 5 September 2017. He states that 'if the only way to save those lives is to subject the terrorist to the most excruciating...pain, what grounds can there be for not doing so?... None.'

103 DERSHOWITZ, Alan. Tortured Reasoning, in Levinson (n 20 above), p. 266. See further STRAUSS, Marcy. Torture (2003-2004). New York Law School Law Review, p. 48, who argues that 'torturing a suspect as a last resort, when there is no alternative and when hundreds, thousands, potentially hundreds of thousands of lives hang in the balance, is not

Published by Palacký University Olomouc, Czech Republic, 2018.

ISSN (print): 1213-8770; ISSN (online): 2464-6601 
There are many difficulties with the ticking time-bomb scenario. Firstly, this scenario is entirely hypothetical and rests on numerous untested assumptions. ${ }^{104}$ What is assumed is the certainty of guilt, the proportionality of the crime to the consequence (that there will be major loss of life), necessity (that there are no other options available), efficacy of torture (that a response will be elicited and that response will be truthful) and control (the torture itself must be applied in a controlled manner so that it meets its objective and nothing more). ${ }^{105}$ The likelihood of such a clear-cut situation occurring is minimal. ${ }^{106}$ Accordingly, it seems doubtful that this scenario, disregarding the rights of one in order to allegedly preserve the rights of many, can be used to extrapolate a general exception or limitation to the use of torture. ${ }^{107}$

In addition to the above, in 2006 the German Federal Constitutional Court made it clear that that collective goods may not, under any circumstances, outstrip individual rights, and afforded individual liberty a higher stake than collective security. ${ }^{108}$ The matter heard by the Constitutional Court concerned a complaint regarding the constitutionality of section 14(3) of the Aviation Security Act (Luftsicherheitsgesetz), which entered into effect on 15 January 2005 (the Aviation Security case). ${ }^{109}$ Sections $14(3)$ and (4) of this act stated as follows:

(3) The direct use of armed force is permissible only where it must be assumed under the circumstances that the aircraft is intended to be used against human lives, and where this is the only means to avert the imminent danger.

(4) The measure pursuant to subsection 3 can only be ordered by the Federal Minister of Defence, or in the event of the Minister of Defence having to be represented, by the member of the Federal Government who is authorised to represent the Minister.

Sections 14(3) and (4) therefore empowered the Minister of Defence to order that a passenger airplane be shot down, if it could be assumed that the aircraft would be used as a weapon against the lives of others and downing the aircraft

morally bankrupt - it is the only conclusion that makes sense.'

104 See KOLA (n 101 above), p. 99-109.

105 Ibid.

106 KOLA (n 101 above), p. 98.

107 See further BUFACCHI, Vittorio \& ARRIGO, Jean Maria. Torture, Terrorism and the State: a Refutation of the Ticking-Bomb Argument. Journal of Applied Philosophy, 2006, vol. 23(3), p. 355 (arguing for 'the unconditional refutation of any attempt to justify torture, without exceptions').

108 BVerfG, Judgment of the First Senate of 15 February 2006, 1 BvR 357/05, paras 1-156. [online]. Available at: https://www.bundesverfassungsgericht.de/SharedDocs/Entscheidungen/EN/2006/02/rs20060215_1bvr035705en.html. Accessed: 24 June 2018; LEPSIUS, Oliver. Human Dignity and the Downing of Aircraft: The German Federal Constitutional Court Strikes Down a Prominent Anti-Terrorism Provision in the New Air-Transport Security Act. German Law Journal, vol. 7, no. 9, p. 773.

109 Aviation Security Act, 12 January 2005, Federal Law Gazette I, 78.

Published by Palacký University Olomouc, Czech Republic, 2018.

ISSN (print): 1213-8770; ISSN (online): 2464-6601 
is the only means of preventing this danger. ${ }^{110}$ Such an action would necessarily involve a weighing of rights: weighing the lives of the people in the plane against the lines of those on the ground, and using the presumptive rescue of those on the ground as justification for the death of those innocent citizens in the aircraft. ${ }^{111}$

This case turned on the right to human dignity and the right to life as guaranteed by the German Constitution. The right to human dignity enjoys a prominent position in German law. The incorporation of the right to human dignity as the first clause of the German Constitution was shaped to a great extent by the reaction against Nazi ideology and practice during the Second World War and the horrors of the Holocaust. ${ }^{112}$ In this regard, article 1 of the German Constitution emphasises that the right to human dignity is inviolable and inalienable. ${ }^{113}$ While the right to human dignity is absolute, however, the right to life is subject to restriction by means of the specific enactment of a statute. ${ }^{114}$ In the Aviation Security case, the court noted that any statute that restricts the fundamental right to life must be regarded in the light of the guarantee of human dignity. ${ }^{115}$

The court found that the provisions of the Aviation Security Act which authorised armed forces to shoot down aircraft that were intended to be used as weapons in crimes against human lives, were incompatible with the fundamental right to life and with the guarantee of human dignity to the extent that the use of armed force affected persons on board the aircraft who were not participants in the crime. ${ }^{116}$ Furthermore, the court stated that a state may not protect a major-

110 LEPSIUS (n 108 above), p. 762.

111 Id., p. 763.

112 McCRUDDEN, Christopher. Human Dignity and Judicial Interpretation of Human Rights. European Journal of International Law, 2008, vol. 19, issue 4. Available at: https:// academic.oup.com/ejil/article/19/4/655/349356. Accessed: 30 June 2018.

113 See article 1 of the Basic law for the Federal Republic of Germany (Grundgesetz), 1949. In terms of article 1(1): Die Würde des Menschen ist unantastbar. Sie zu achten und zu schützen ist Verpflichtung aller staatlichen Gewalt ('Human dignity shall be inviolable. To respect and protect it shall be the duty of all state authority'). In terms of article 2(2): 'Das Deutsche Volk bekennt sich darum zu unverletzlichen und unveräußerlichen Menschenrechten als Grundlage jeder menschlichen Gemeinschaft, des Friedens und der Gerechtigkeit in der Welt. (The German people therefore acknowledge inviolable and inalienable human rights as the basis of every community, of peace and of justice in the world). Translation by Professor Christian Tomuschat, Professor David P. Currie and Professor Donald P. Kommers in cooperation with the Language Service of the German Bundestag.

114 Aviation Security case (n 108 above), para C. I, C. II. a) bbb); art 2(2) of the Basic Law (id.) states that 'Jeder hat das Recht auf die freie Entfaltung seiner Persönlichkeit, soweit er nicht die Rechte anderer verletzt und nicht gegen die verfassungsmäßige Ordnung oder das Sittengesetz verstößt'. (Everyone enjoys the right of life and of physical safety. The personal freedom of each individual is inseverable. These rights may only be infringed upon pursuant to a law.) (Own translation.)

115 Ibid.

116 McCRUDDEN (n 112 above).

Published by Palacký University Olomouc, Czech Republic, 2018.

ISSN (print): 1213-8770; ISSN (online): 2464-6601 
ity of its citizens by intentionally killing a minority - in this case, the crew and the passengers of a plane. ${ }^{117}$ A weighing up of lives against lives, according to the standard of how many people are possibly affected on the one side and how many on the other side, is impermissible. ${ }^{118}$ It has been argued that the court's reasoning for striking down the impugned provisions of the Aviation Act focused on the right to human dignity and not the right to life, and as such, the decision effectively decoupled the right to human dignity from the right to life. The court could thus have limited the reasoning to the human dignity clause alone without relying on the right to life in article 2(2) of the German Constitution. ${ }^{119}$

The Aviation Security case illustrates that the right to human dignity is absolute, inviolable and indivisible in all circumstances - whether a possible limitation of the right is contemplated towards the achievement of a greater good, makes no difference. Accordingly, there is no scope for the limitation of the prohibition of torture by arguing that the rights of one terrorist should be sacrificed for the rights of many civilians, or that the limitation of the prohibition of torture is justified as it is for the greater good, i.e. the fight against terrorism. The next paragraph will consider whether a limitation of the prohibition of torture is possible where there is a norm conflict, i.e. where both the prohibition of the use of torture and the prohibition of terrorism are jus cogens or peremptory norms from which no derogation is permitted.

\subsection{The prohibition of the use of torture and the prohibition of terrorism}

\subsubsection{Jus cogens norms}

The prohibition of terrorism has attained the status of a jus cogens norm. ${ }^{120}$ In terms of article 53 of the Vienna Convention on the Law of Treaties:

...a peremptory norm of general international law (jus cogens) is a norm accepted and recognized by the international community of states as a whole as a norm from which no derogation is permitted and which can be modified only by a subsequent norm of general international law having the same character. ${ }^{121}$

State practice supports the prohibition of terrorism as a norm of customary international law, and therefore a norm of general international law. ${ }^{122}$ International treaties and protocols criminalising terrorist conduct enjoy widespread rati-

117 See Aviation Security case (n 108 above), reasons for judgment, at A II. 2, C. II. bb) bbb). 118 Ibid.

119 Id., II b) aa).

120 For a full analysis of this argument, see DE BEER (n 22 above), chapter 3.

121 Art 53 of the Vienna Convention (n 35 above), p. 18-19.

122 The ILC Study Group on Fragmentation used the term 'general international law' to denote both customary rules and general principles of law. See Analytical Report of the Study Group of the International Law Commission finalised by Chairman Martti Koskenniemi. Fragmentation of International Law: Difficulties Arising from the Diversification and Expansion of International Law, UN Doc A/CN4/L682, 13 April 2006, p. 92, 194. 
fication. ${ }^{123}$ Most states in the world have adopted national legislation prohibiting terrorism. ${ }^{124}$ A norm of customary international law is elevated to a norm of jus cogens though the recognition of the international community as a whole that no derogation from such a norm is permitted. ${ }^{125}$ In this regard, the consistent and repeated condemnation of acts of terrorism by states and the reiteration that nothing can ever justify terrorism illustrate this opinio juris of states regarding the prohibition of terrorism. ${ }^{126}$

123 The Convention on Offences and Certain Other Acts Committed on Board Aircraft, 1963 (Tokyo Convention), the International Convention against the Taking of Hostages, 1979; the Convention for the Suppression of Unlawful Acts against the Safety of Maritime Navigation, 1988; the International Convention for the Suppression of Terrorist Bombings, 1999; the Convention for the Unification of Certain Rules for International Carriage by Air, 1999 (Montreal Convention); the International Convention for the Suppression of the Financing of Terrorism, 1999; the International Convention for the Suppression of Acts of Nuclear Terrorism, 2005.

124 See South Africa's Protection of Constitutional Democracy Against Terrorist and Related Activities Act 33 of 2004; the Botswana Counter-Terrorism Act 24 of 2014; the Lesotho Penal Code Act 6 of 2012; the Uganda Anti-Terrorism Act, 2002; the Ghana Anti-Terrorism Act 762 of 2008; the Nigerian Terrorism (Prevention) Act, 2011; the Cameroon Law on the Suppression of Acts of Terrorism 28 of 2014; sec 87bis of the Algerian Penal Code, promulgated by Order No. 66-156 of 18 Safar 1386 corresponding to 8 June, 1966; the Egyptian Anti-Terrorism Law, 2015; the Tanzanian Prevention of Terrorism Act, 2002; the Ethiopian Anti-Terrorism Proclamation no 652 of 2009; the Tunisian Anti-Terrorism Law 26 of 2015; sec 329 of the Penal Code of Bhutan, 2008; the Bangladesh Anti-Terrorism Ordinance, 2004; sec 130B of the Malaysian Penal Code Act 574 of 2015; sec 218bis of the Penal Code of the Democratic Republic of Timor Leste 19 of 2009; the Jamaican Terrorism Prevention Act, 2005; the Seychelles Prevention of Terrorism Act 7 of 2004; the Dominican Suppression of the Financing of Terrorism (Amendment) Act 10 of 2011; sec 73C of the Vanuatu Penal Code [Cap 135] 1981; the Antigua and Barbuda Prevention of Terrorism Act of 2005; the Trinidad and Tobago Anti-Terrorism Act 26 of 2005; arts 571-580 of the Penal Code of Spain, 1995 (as amended by Organic Law 5/2010); sec 8(1) para 2(b) of the Belgian Organic Law on the Intelligence and Security Services, 1998; the Netherlands Crimes of Terrorism Act, 2004; sec 311 of the Criminal Code of the Czech Republic Act 40 of 2009; sec 258 of the Criminal Code of Ukraine, 2001; sec 330 of the Criminal Code of the Republic of Albania, Law no 7895 of 1995; sec 230 of the Andorra New Penal Code, 2005; the Saudi-Arabia Penal Law for Crimes of Terrorism and its Financing, 2013; sec 100(1) of the Australian Criminal Act Code, 1995; the New Zealand Terrorism Suppression Act, 2002; sec 1 of 18 USC 2331, 2004; sec 3 of the Bahamas Anti-Terrorism Act, 2004; sec 391 of the Guatamalan Criminal Code, 1973; sec 2 of the Brazilian Anti-Terrorism Law, 2016; sec 421 of the French Penal Code, 1791.

125 Art 53 of the Vienna Convention (n 35 above).

126 Summary Records of the Sixth Committee, 28th meeting Official Records of the General Assembly, Sixty-Ninth Session, A/C6/55/SR28 (7 October - 14 November 2014). [online]. Available at: https://papersmart.unmeetings.org/ga/69th-session/general-debate/statements/. Accessed: 8 August 2017. See for example the statements by Mr GH Dehghani of the Islamic Republic of Iran ('...the Non-Aligned Movement condemns terrorism in all its forms and manifestations, wherever, by whoever and against whomsoever committed... which are unjustifiable whatever consideratons or facts that may be invoked to justify them...'); Mr E Zagaynov on behalf of the member states of the Shanghai Co-operation Organisation and the Russian Federation (reiterating the '...fundamental position of con-

Published by Palacký University Olomouc, Czech Republic, 2018.

ISSN (print): 1213-8770; ISSN (online): 2464-6601 
As regards the prohibition of torture, the jus cogens status of this prohibition is widely accepted. ${ }^{127}$ States, such as the US, have publicly condemned torture, ${ }^{128}$ and

demning terrorism in all its forms and manifestations, regardless of its motivation, whenever, wherever and by whomsoever committed'; Ms E Cujo on behalf of the European Union ( ...the international community must respond jointly by condemning terrorism in all its forms and manifestations'); Mr T Joyini on behalf of South Africa (speaking for the African Group): 'There is no justification for terrorism. African states strongly and unequivocally condemn terrorism in all its forms and manifestations, as well as all acts, methods and practices of terrorism wherever, by whomever, against whomever committed, including state terrorism. For no cause or grievance can terrorism be justified'); Mr A Heumann on behalf of Israel ('Israel wishes to reaffirm its strong commitment to counter terrorism and its uncompromising condemnationof terrorism in all its forms and manifestations, irrespective of its motivations'); See, further, 8th BRICS Summit - Goa Declaration, 16 January 2017, para 57 [online]. Available at: https://brics2017.org/English/Documents/Summit/201701/t20170125_1410.html. Accessed 26 October 2017: 'We strongly condemn terrorism in all its forms and manifestations and stressed that there can be no justification whatsoever for any acts of terrorism, whether based upon ideological, religious, political, racial, ethnic or any other reasons'; D Pollock \& M Abdelaziz 'Arab states condemn "terrorist" Paris attacks. Available at: http://english.alarabiya.net/en/News/ middle-east/2015/11/14/Arab-states-denounce-Paris-attacks-as-violation-of-human-values-.html Accessed: 1 December 2016; US Department of State. United States Condemns Terrorist Attack on Istanbul's Ataturk Airport, 28 June 2016, [online]. http://www.state. gov/r/pa/prs/ps/2016/06/259153.htm. Accessed: 7 August 2016; G20 Statement on the Fight Against Terrorism, [online]. Available at: http://www.consilium.europa.eu/en/meetings/international-summit/2015/11/g20-statement-on-the-fight-against-terrorism_pdf/. Accessed: 7 August 2016.

127 In Tachiona v Mugabe, 169 F. Supp. 2d 259, SDNY 2001, p. 264, 279, the US District Court for New York noted that 'torture is among the practices defined in the world's nations, through treaties, conventions and declarations' as being violations of customary international law, non-derogable in all situations and as a jus cogens norm. It further noted that ' $[\mathrm{t}]$ he world's nations, through treaties, conventions and declarations, have established standards defining as violations of customary international law, practices such as genocide, crimes against humanity, torture, forced disappearance, extra-judicial killings and terrorism.' See further Siderman de Blake v Republic of Argentina 965 F 2d 699, 9th Cir 1992, p. 717: ' $[\mathrm{t}]$ he right to be free from torture is fundamental and universal, a right deserving of the highest stature under international law, a norm of jus cogens'. See further Kazemi Estate v Islamic Republic of Iran 2014 SCC 151-152; Torture and Other Cruel, Inhuman or Degrading Treatment or Punishment, report by Special Rapporteur, Mr P Kooijmans, UN Doc E/CN4/1986/15 (1986) 1 para 3, stating that torture is absolutely forbidden; Belgium v Senegal (Questions Relating to the Obligation to Prosecute or Extradite) (20 July 2012) (2012) ICJ Reports, paras 99-100. Koigi Wamwere v the Attorney-General (2015) eKLR 6. The Kenyan Court of Appeal noted that the prohibition of torture 'is a principle of jus cogens and is a peremptory norm of international law'; Filartiga v Pena-Irala 630 F 2d 876 (2d Cir 1980) 882-83; R v Bow Street Metropolitan Stipendiary Magistrate, Ex parte Pinochet Ugarte (No 3) (2000) 1 AC 147 \& Prosecutor v Furundzija (1998) 38 ILM 317 para 164. para 144.

128 See for example, US Department of State. Initial Report of the United States of America to the UN Committee against Torture, 15 October 1999, p. 6. Available at: https://1997-2001. state.gov/global/human_rights/torture_index.html. Accessed: 1 July 2018. See further US Department of State. Second Periodic Report of the United States of America to the UN Committee against Torture, 6 May 2005, pp. 4, 17. Available at: https://www.state.gov/j/drl/ rls/45738.htm. Accessed: 1 July 2018. See TRUMP, Donald J. National Security Strategy of

Published by Palacký University Olomouc, Czech Republic, 2018.

ISSN (print): 1213-8770; ISSN (online): 2464-6601 
the International Court of Justice in Belgium $v$ Senegal stated that the prohibition on torture is part of customary international law and had become a peremptory norm (jus cogens). ${ }^{129}$

Accordingly, this discussion is based on the premise that both the prohibition of torture and the prohibition of terrorism are norms of jus cogens from which no derogation is permitted. The question arises whether, and how, a possible legal antinomy or norm conflict should be resolved. A legal antinomy arises where two contrary legal commandments cannot be applied in their entirety to the same situation, and the normative conflict must be solved by either harmonising the competing norms or applying one to the detriment of the other. ${ }^{130}$ In situations of antinomy, solving the conflict may involve the invalidity or the limitation of one of the norms or the maintenance of both as valid after the antinomy has been solved. ${ }^{131}$ It may further involve a weighing of the norms concerned, i.e. specifying the interests protected by the competing norms and assigning relative weights to each interest. ${ }^{132}$ The underlying norms protected by the prohibition of terrorism and the prohibition of torture will thus be considered in evaluating whether there is any justification for the limitation of the prohibition of torture in the fight against terrorism.

Jus cogens norms have certain characteristics - they seek to protect fundamental, basic or higher interests, or fundamental humanitarian values, are hierarchically superior and are universally applicable. ${ }^{133}$ One of the fundamental values pro-

the United States of America. December 2016, [online]. Available at: https://www.whitehouse.gov/wp-content/uploads/2017/12/NSS-Final-12-18-2017-0905-2.pdf. Accessed: 16 June 2018. See further US Army Field Manual, viii FM2-22.3. Human Intelligence Collector Operations, pp. 20-25. [online]. September 2006. Available at: https://fas.org/irp/ doddir/army/fm2-22-3.pdf. Accessed: 17 June 2018.

129 Belgium v Senegal (n 126 above), paras 99-100. It stated that the prohibition against torture: 'is grounded in a widespread international practice and the opinio juris of states. It appears in numerous international instruments of universal application (in particular the Universal Declaration of Human Rights of 1948, the 1949 Geneva Conventions for the protection of war victims; the International Covenant on Civil and Political Rights of 1966; General Assembly resolution 3452/30 of 9 December 1975 on the Protection of All Persons from Being Subjected to Torture and Other Cruel, Inhuman or Degrading Treatment or Punishment), and it has been introduced into the domestic law of almost all states; finally, acts of torture are regularly denounced within national and international fora'.

130 PERELMAN, Chaïm. Les Antinomies en Droit, Essay de synthèse. In PERELMAN, Chaïm (ed.), Les antonomies en droit, Bruxelles, 1965, p. 393.

131 CHRISTÓFOLO, João Ernesto. Solving Antinomies Between Peremptory Norms in Public International Law. Geneva: Schulthess, 2016, p. 24.

132 ALEXY, Robert. A Theory of Constitutional Rights, Oxford: Oxford University Press, 2010, pp. 64-68.

133 See TLADI, Dire. Second report on Jus Cogens. In UN Report of the International Law Commission 69th session (1 May - 2 June and 3 July - 4 August 2017) A/CN4/706, p. 9. para 18; Furundzija (n 127 above), para 153. In the Furundžija case, the ICJ stated that the prohibition of torture as a norm of jus cogens relates to 'the hierarchy of rules in the international normative order,' and claimed that it has evolved into a jus cogens norm which

Published by Palacký University Olomouc, Czech Republic, 2018.

ISSN (print): 1213-8770; ISSN (online): 2464-6601 
tected by jus cogens norms is the right to human dignity. ${ }^{134}$ The fundamental nature of the right to human dignity was illustrated in section 4.1 above. Both the prohibition of terrorism and the prohibition of torture protect this right. Acts of terrorism are committed with the intent to spread fear amongst innocent civilians. ${ }^{135}$ This infringes on the basic right to human dignity and the right of human beings not to be used as instruments for the furtherance of a political or ideological goal. ${ }^{136}$ As regards torture, according to a report by Amnesty International, '[e]very time a helpless individual is being tortured, our own dignity and humanity is being

has a higher rank in the international hierarchy than treaty law and customary rules. Jus cogens norms have been described as 'universally binding by their very nature. See Smith v Socialist People's Libyan Arab Jamahiriya 101 F 3d 239 (2nd Cir 1996) 242. See further re the universally binding nature of jus cogens norms, Tel-Oren v Libyan Arab Republic (Judgement of 3 February 1984) 726 F2d 774, 233 (US App DC) 384; Siderman de Blake (n 127 above) 715 . With regards to national case law re the importance of the values underlying jus cogens obligations, see Sentencia del Pleno Jurisdiccional del Tribunal Constitucional del Perú Exp n 0024-2010-PI/TC 53; Kaunda \& Others v President of the Republic of South Africa \& Others (Society for the Abolition of the Death Penalty in South Africa intervening as Amicus Curiae) 20054 SA 235 (CC); Alvarez-Machain v United States 331 F 3d 604 (2003, 9th Cir) 613. For international case law re values underlying jus cogens obligations, see Belgium v Senegal (n 126 above) 1, 84 \& 182 (separate opinion of Judge Cançado Trindade); Application of the Convention on the Prevention and Punishment of the Crime of Genocide (Croatia v Serbia) (3 February 2015) (2015) ICJ Reports para 160. For statements by states confirming that jus cogens norms protect fundamental values, for example, see Germany, 55th session of the UN General Assembly, Sixth Committee, Agenda Item 159: 'Report on the work of the 52nd session (2000)' para 56; Finland, 52nd Meeting of the Committee of the Whole 'UN Conference on the Law of Treaties First Session Vienna' (26 March - 24 May 1968). Portugal, 56th Session of the UN General Assembly, Sixth Committee, Agenda Item 162: 'Report of the International Law Commission on the work of its 53rd session' (2001) para 66. South Africa, 55th Session of the UN General Assembly, Sixth Committee Agenda Item 159: 'Report of the International Law Commission on the work of its 52nd session' (2000) para 29.

134 SIMMA, Bruno \& ALSTON, Philip. The Sources of Human Rights Law: Custom, Jus Cogens, and General Principles. European Journal of International Law, 1995, vol. 6, p. 43. See further the preamble of the Inter-American Convention to Prevent and Punish Torture, 1985 (IACPPT), reaffirms that 'all acts of torture or any other cruel, inhuman, or degrading treatment or punishment constitute an offense against human dignity...' As early as 1988, the Preamble to the Maritime Safety Convention (n 123 above) referred to the 'world-wide escalation of acts of terrorism in all its forms, which endanger or take innocent human lives, jeopardize fundamental freedoms and seriously impair the dignity of human beings.'

135 Para 3 of S/RES/1566 (2004) (threats to international peace and security); Prosecutor v Ayyash et al (STL-11-01/I), Interlocutory Decision on the Applicable Law: Terrorism, Conspiracy, Homicide, Perpetration, Cumulative Charging, Appeals Chamber, 16 February 2011 paras 42-62; Count 1: Infliction of terror, Prosecutor v. Stanislav Galić Case No. IT-98-29-I, Indictment, 26 March 1999, para 41; Legal Consequences of the Construction of a Wall in the Occupied Palestinian Territory 2004 ICJ Reports 136, para 4-5.

136 WEATHERALL, Thomas. The Status of the Prohibition of Terrorism in International Law: Recent Developments. Georgetown Journal of International Law, 2015, vol. 46, p. 589. 609.

Published by Palacký University Olomouc, Czech Republic, 2018.

ISSN (print): 1213-8770; ISSN (online): 2464-6601 
diminished and degraded' and there is no act which is 'more a contradiction of our humanity than the deliberate infliction of pain by one human being on another, the deliberate attempt over a period of time to kill a man without his dying. ${ }^{137}$

Case law supports the argument that no derogation from the right to human dignity is supported, in finding that the prohibition of torture is absolute even in the context of counter-terrorism measures. In domestic jurisprudence, the Spanish Supreme Court condemned the use of torture and ill-treatment, including physical abuse and threats, against terrorist suspects during incommunicado detention. ${ }^{138} \mathrm{In}$ Public Committee Against Torture in Israel v the State of Israel, the Supreme Court of Israel rejected the Government's arguments on possible justifications for the use of physical means during the interrogation of individuals suspected of hostile terrorist activities. ${ }^{139}$ Israel's High Court of Justice found that 'lighter forms' of torture, such as shaking, are not allowed during the interrogation of suspects of terrorism, even if they were going to prevent foreseeable attacks planned in the near future ${ }^{140}$ In other cases, the ECtHR has confirmed that, even in the most difficult circumstances such as the fight against terrorism, torture and inhuman or degrading treatment or punishment are prohibited in absolute terms irrespective of the conduct of the person concerned. ${ }^{141}$ Any limitation of the prohibition of torture is a slippery slope and opens the door to government abuse. For example, after the Landau Commission of Inquiry of 1987 permitted 'moderate physical pressure' in the interrogation of detainees suspected of hostile terrorist activity, the Israeli human rights group B'Tselem estimates that security services used torture against $85 \%$ of Palestinian detainees under interrogation. ${ }^{142}$

137 Amnesty International (n 21 above), p. 11, 25. See further Attorney General of Israel v Adolf Eichmann, District Court of Jerusalem, 36 ILR 18, 25, 26, 50 (Israel Dist Ct 1961).

138 Case of Igor Portu and Mattin Sarasola Spanish Supreme Court (2 November 2011). See further Amnesty International 'Spain: Civil Guards Convicted of Torture' (10 January 2011) http://www.amnesty.org/en/library/asset/EUR41/002/2011/en/60b24c89-11154124-aa36-68f3705efc84/eur410022011en.html (accessed 1 May 2017).

139 Public Committee Against Torture v State of Israel HCJ 5100/94 (1999) 817.

140 Id. 24.

141 Labita v Italy Application no 26772/95 ECHR (6 April 2000) para 119; see further Gäfgen v Germany Application no 22978/05 (1 June 2010) 87; Ramirez Sanchez v France Application no 59450/00 (4 July 2006) para 116; Al-Adsani v UK (2001) 34 EHRR 273, 123 ILR 24 para 59. In Chahal v United Kingdom Application no 22414/93 ECHR (5 November 1996) para 79, the Court noted that it is 'well aware of the immense difficulties faced by states in modern times in protecting their communities from terrorist violence. However, even in these circumstances, the Convention prohibits in absolute terms torture or inhuman or degrading treatment or punishment, irrespective of the victim's conduct...' See further Soering v The United Kingdom (n 84 above) 88.

142 The Guardian 'Israeli Government Report admits Systematic Torture of Palestinians' https://www.theguardian.com/world/2000/feb/11/israel (accessed 13 August 2017). See further Commission of Inquiry into the Methods of Investigation of the General Security Service Regarding Hostile Terrorist Activity (1989) https://www.cambridge.org/core/journals/ israel-law-review/article/commission-of-inquiry-into-the-methods-of-investigation-ofthe-general-security-service-regarding-hostile-terrorist-activity/2feeb59b40b66a4le9ff-

Published by Palacký University Olomouc, Czech Republic, 2018.

ISSN (print): 1213-8770; ISSN (online): 2464-6601 
With regard to a possible weighing of the underlying interests protected by the jus cogens norms of the prohibition of terrorism and the prohibition of torture respectively, both norms protect the same fundamental value, namely the right to human dignity. Accordingly, there can be no balancing or limitation of values in order to arrive at any type of normative hierarchy.

\section{Conclusion}

This article explored the controversial issue of the use of techniques that amount to torture under international law in the fight against terrorism. In order to consider which acts would amount to prohibited torture during counter-terrorism measures, it evaluated state practice with regard to the element of severe pain and suffering. It found support for the evolution of a view that 'severity' is a relative concept and depends on all the circumstances of the case, including the duration of the treatment, its physical or mental effects, as well as the sex, age and state of health of the victim. Accordingly, certain acts which had in the past been classified as inhuman and degrading treatment and not torture for lacking the requisite degree of severity, would now amount to torture. This would include the psychological 'stress and duress' techniques to which terrorist suspects have allegedly been subjected at Abu Graib and Gauntanamo Bay in the US.

Furthermore, it was found that the use of torture cannot be justified by utilitarian arguments, i.e. that the torture of one terrorist suspect is justifiable to save the lives of many. The right to human dignity which underlies the prohibition of torture is inviolable and this right cannot be sacrificed for the greater good; the right in itself protects the greater good. Finally, while the prohibition of torture and the prohibition of terrorism are both norms of jus cogens, no norm weighing or normative hierarchy is possible as both norms protect the right to human dignity. In violating the right to human dignity by seeking to justify limitations to the absolute prohibition of torture in the fight against terrorism, states will ultimately destroy the same rights which they seek to protect.

\section{References}

\section{Books}

ALEXY, Robert. A Theory of Constitutional Rights. Oxford, Oxford University Press, 2010, pp. 64-68.

CHRISTÓFOLO, João Ernesto. Solving Antinomies Between Peremptory Norms in Public International Law. Geneva: Schulthess, 2016, p. 24.

DERSHOWITZ, Alan. Tortured Reasoning, in LEVINSON, Stanford (ed). Torture: A Collection. Oxford: Oxford University Press, 2004, p. 266.

3633c0d3bf69 (accessed 26 October 2017). The Commission's recommendations were struck down by the Supreme Court - see Public Committee Against Torture v State of Israel MCJ 5100/94 (1999) 817.

Published by Palacký University Olomouc, Czech Republic, 2018.

ISSN (print): 1213-8770; ISSN (online): 2464-6601 
EDGERTON, Robert B. The Worldwide Practice of Torture. New York: Edwin Mellen Press Ltd, 2007.

FEIN, Helen. Human Rights and Wrongs: Slavery, Terror, Genocide. Colorado: Paradigm Publishers, 2007, pp. 63-76.

GUR-ARYE, Miriam. Can the War against Terror Justify the Use of Force in Interrogations? Reflection in Light of the Israeli Experience in LEVINSON, Stanford (ed). Torture: A Collection. Oxford: Oxford University Press, 2004.

KRAUTHAMMER, Charles. The Truth about Torture in LEVINSON, Stanford (ed). Torture: A Collection. Oxford: Oxford University Press, 2004.

LEVINSON, Stanford (ed). Torture: A Collection. Oxford: Oxford University Press, 2004, p. 294.

PERELMAN, Chaïm. Les Antinomies en Droit, Essay de synthèse. In PERELMAN, Chaïm (ed.), Les antonomies en droit, Bruxelles, 1965, p. 393.

POSNER, Richard. Torture, Terrorism, and Interrogation. In LEVINSON, Stanford (ed). Torture: A Collection. Oxford: Oxford University Press, 2004, p. 294.

WALZER, Michael. Political Action: The Problem of Dirty Hands, in LEVINSON, Stanford (ed). Torture: A Collection. Oxford: Oxford University Press, 2004.

\section{Journal Articles}

BELLAMY, Alex J. No pain, no gain? Torture and Ethics in the War on Terror. International Affairs, 2006, vol. 82(1), pp. 121-148.

BUFACCHI, Vittorio \& ARRIGO, Jean Maria. Torture, Terrorism and the State: a Refutation of the Ticking-Bomb Argument. Journal of Applied Philosophy, 2006, vol. 23(3), p. 355.

BUHA, Mark J. Rule Utilitarian and Deontologist Perspectives on Comparisons of Torture and Killing. Washington University Juridical Review, 2010, vol. 2, p. 304.

DANELIUS, Hans. Torture and Cruel, Inhuman or Degrading Treatment or Punishment. Nordic Journal of International Law, 1959, vol. 58, p. 180.

DERSHOWITZ, Alan. The Torture Warrant: a Response to Professor Strauss. New York Law School Law Review, 2003, vol. 48, p. 275.

HATHAWAY, Oona. Do Human Rights Treaties Make a Difference? Yale Journal of International Law, 2002, p. 1935.

GERT, Bernard. Justifying Violence. The Journal of Philosophy, 1969, vol. 66, p. 623.

KOLA, Fatima. Torture and Terrorism - a case study. Supplement UCL Jurisprudence Review, 2007, pp. 85, 97.

LEPSIUS, Oliver. Human Dignity and the Downing of Aircraft: The German Federal Constitutional Court Strikes Down a Prominent Anti-Terrorism Provision in the New Air-Transport Security Act. German Law Journal, vol. 7, no. 9, p. 773.

LIPPMAN, Matthew. The Development and Drafting of the United Nations Convention Against Torture and Other Cruel Inhuman or Degrading Treatment or Punishment. Boston College International and Comparative Law Review, 1994, vol. 17, pp. 314-315.

MACMASTER, Neil. Torture: From Algiers to Abu Ghraib. Race and Class, 2004, vol. 46(2), p. 12.

McCRUDDEN, Christopher. Human Dignity and Judicial Interpretation of Human Rights. European Journal of International Law, 2008, vol. 19, issue 4. Available at:

Published by Palacký University Olomouc, Czech Republic, 2018.

ISSN (print): 1213-8770; ISSN (online): 2464-6601 
https://academic.oup.com/ejil/article/19/4/655/349356. Accessed: 30 June 2018. RODLEY, Nigel. The Prohibition of Torture: Absolute Means Absolute. Denver Journal of International Law \& Policy, 2006, vol. 34, pp. 145-160.

STRAUSS, Mary. Torture (2003-2004). New York Law School Law Review, p. 48.

SIMMA, Bruno \& ALSTON, Philip. The Sources Of Human Rights Law: Custom, Jus Cogens, and General Principles. European Journal of International Law, 1995, vol. 6, p. 43.

WEATHERALL, Thomas. The Status of the Prohibition of Terrorism in International Law: Recent Developments. Georgetown Journal of International Law, 2015, vol. 46, p. 589.

\section{Treaties and Declarations}

African Charter on Human and Peoples' Rights, 1981.

American Convention of Human Rights, 1969.

Convention on Offences and Certain Other Acts Committed on Board Aircraft, 1963.

Convention for the Suppression of Unlawful Acts against the Safety of Maritime Navigation, 1998

Convention against Torture and Other Cruel, Inhuman or Degrading Treatment or Punishment, 1984.

Convention for the Unification of Certain Rules for International Carriage by Air, 1999.

Declaration on the Protection of All Persons from Being Subjected to Torture or Other Cruel, Inhuman or Degrading Treatment or Punishment, 1975.

European Convention for the Protection of Human Rights and Fundamental Freedoms, 1950.

Inter-American Convention to Prevent and Punish Torture, 1985.

International Convention for the Suppression of Acts of Nuclear Terrorism, 2005.

International Convention for the Suppression of the Financing of Terrorism, 1999.

International Convention for the Suppression of Terrorist Bombings, 1999.

International Convention against the Taking of Hostages, 1979.

International Covenant on Civil and Political Rights, 1966.

United Nations Charter, 1945.

Vienna Convention on the Law of Treaties, 1969.

\section{Security Council Resolutions}

S/RES 1373 (2001).

S/RES 1624 (2005).

\section{Case law}

\section{International Courts and Tribunals}

Application of the Convention on the Prevention and Punishment of the Crime of Genocide (Croatia v Serbia) (3 February 2015) (2015) ICJ Reports para 160.

Belgium $v$ Senegal (Questions Relating to the Obligation to Prosecute or Extradite) (20 July 2012) (2012) ICJ Reports, paras 99-100. 
Legal Consequences of the Construction of a Wall in the Occupied Palestinian Territory 2004 ICJ Reports 136. para 4-5.

Prosecutor v Ayyash et al (STL-11-01/I), Interlocutory Decision on the Applicable

Law: Terrorism, Conspiracy, Homicide, Perpetration, Cumulative Charging,

Appeals Chamber, 16 February 2011 paras 42-62.

Prosecutor v Furundzija (1998) 38 ILM 317 para 164. para 144.

Prosecutor v Stanislav Galić Case No. IT-98-29-I, Indictment, 26 March 1999, para 41.

\section{African Commission}

African Commission, Abdel Hadi, Ali Radi \& Others v Republic of Sudan, Communication 368/09 (5 November 2013) para 71.

\section{Inter-American Commission and Inter-American Court of Human Rights}

Durand and Ugarte v Peru, IACHR, 16 August 2000, Ser C, No 68, para 59.

Loayza-Tamayo $v$ Peru, IACtHR, 17 September 1997, Series C No 33, para 57.

Mejía v Peru, IACHR, 1 March 1996, OEA/SerL/V/II91 Doc 7 sec B, para 2.

Morales $v$ Guatemala Inter-American Commission of Human Rights, IAm Comm of HR (8 March 1998) Ser C No 37134.

\section{UN Human Rights Committee}

Communication 110/1981, Acosta v Uruguay, UNHR Committee, 12 August 1981, UN Doc Supp no 40, A/39/40, 1984, para 14.

Communication 88/1981, Bequio v Uruguay, UNHR Committee, 14 March 1981, UN Doc CCPR/C/OP/2 (1990), para 12.

Communication 105/1981, Cabreira v Uruguay, UNHR Committee, 7 August 1981, UN Doc CCPR/C/OP/2 (1990), para 11.

Communication 176/1984, Lafuente Peñarrieta et al. $v$ Bolivia, UNHR Committee, 2

November 1987, UN Doc CCPR/C/OP/2 201 (1990), paras 1.3, 10.4.

Communication 74/1980, Miguel Angel Estrella v Uruguay, UNHR Committee, 17 July 1980, UN Doc Supp No 40 (A/38/40) 150 (1983) para 1.6.

\section{European Commission and European Court of Human Rights}

Chahal $v$ United Kingdom Application no 22414/93 ECHR (5 November 1996), para 79.

Gäfgen v Germany Application no 22978/05 (1 June 2010) 87.

Ireland $v$ the United Kingdom, Application no 5310/71, ECHR, judgement, 18 January 1978, para 167.

Ireland $v$ the United Kingdom EC (1976) 512 Yearbook of European Convention on Human Rights 489-491.

Labita v Italy Application no 26772/95 ECHR (6 April 2000), para 119.

Ramirez Sanchez v. France Application no 59450/00 (4 July 2006), para 116.

Selmouni v France, Application no 25803(94), ECHR, 1 December 1977, paras 20, 24. Soering $v$ United Kingdom, Application 14038/88, ECHR, 7 July 1989, p. 40, para 91, sec 102.

The Greek Case Report of the Commission: Application no 3321/67-Denmark v Greece, 
Application no 3322/67-Norway v Greece, Application no 3323/67-Sweden v Greece, Application no 3344/67-Netherlands v. Greece (1970) EC 11.

\section{Domestic case law}

Al-Adsani v UK (2001) 34 EHRR 273, 123 ILR 24 para

Alvarez-Machain v United States 331 F 3d 604 (2003, 9th Cir) 613.

A \& Others $v$ Secretary of State for the Home Department (No 2), (2005) (HL)1 WLR 53 Ashcraft $v$ Tennessee 322 US 143, 155 (1944).

Attorney General of Israel v Adolf Eichmann, District Court of Jerusalem, 36 ILR 18,

25, 26, 50 (Israel Dist Ct 1961).

Case of Igor Portu and Mattin Sarasola Spanish Supreme Court (2 November 2011). Flatow v Islamic Republic of Iran 999 F Supp 23 (DDC 1998).

Filartiga v Pena-Irala 630 F 2d 876 (2d Cir 1980) 882-83.

Kaunda \& Others $v$ President of the Republic of South Africa \& Others (Society for the Abolition of the Death Penalty in South Africa intervening as Amicus Curiae) 2005 4 SA 235 (CC).

Kazemi Estate v Islamic Republic of Iran 2014 SCC 151-152.

Koigi Wamwere $v$ the Attorney-General (2015) eKLR 6.

Loizidou v Turkey, 23 March 1995, Series A, no 310, p. 26, sec 71.

Nulyarimma $v$ Thompson (1999) FCA 1192 (1 September 1999) 145.

$R v$ Bow Street Metropolitan Stipendiary Magistrate, Ex parte Pinochet Ugarte (No 3) (2000) 1 AC 147.

Sentencia del Pleno Jurisdiccional del Tribunal Constitucional del Perú Exp n 00242010-PI/TC 53.

Siderman de Blake v Republic of Argentina 965 F 2d 699 (9th Cir 1992).

Smith v Socialist People's Libyan Arab Jamahiriya 101 F 3d 239 (2nd Cir 1996) 242.

Tachiona v Mugabe, 169 F. Supp. 2d 259, SDNY 2001, p. 264, 279.

Tel-Oren v Libyan Arab Republic (Judgement of 3 February 1984) 726 F2d 774, 233

(US App DC) 384.

Tyrer $v$ the United Kingdom, 25 April 1978, Series A no 26, p. 15, para 31.

Public Committee Against Torture v State of Israel HCJ 5100/94 (1999) 817.

Xuncax v Gramajo 886 FSupp (D Mass 1995) 162, 174, 178.

\section{Domestic legislation}

Algerian Penal Code, promulgated by Order No. 66-156 of 18 Safar 1386 corresponding to 8 June, 1966.

Andorra New Penal Code, 2005.

Antigua and Barbuda Prevention of Terrorism Act of 2005.

Arabian Law of Criminal Procedure of 16 October 2001.

Armenian Criminal Code, 2003.

Australian Criminal Act Code, 1995

Aviation Security Act, 12 January 2005, Federal Law Gazette I, 78.

Bahamas Anti-Terrorism Act, 2004.

Bangladesh Anti-Terrorism Ordinance, 2004.

Basic Law for the Federal Republic of Germany, 1949.

Belgian Organic Law on the Intelligence and Security Services, 1998.

Published by Palacký University Olomouc, Czech Republic, 2018.

ISSN (print): 1213-8770; ISSN (online): 2464-6601 
Brazilian Anti-Terrorism Law, 2016.

Botswana Counter-Terrorism Act 24 of 2014.

Cameroon Law on the Suppression of Acts of Terrorism 28 of 2014.

Canadian Criminal Code, 1985.

Cameroon Penal Code, 1967.

Columbia Penal Code Law no 599 of 2000.

Constitution of the Bolivarian Republic of Venezuela, 1999.

Constitution of Cameroon, 1972.

Constitution of Colombia, 1991.

Constitution of the Democratic Republic of the Congo, 2005.

Constitution of Greece, 1975 (as amended).

Constitution of Kenya, 2010.

Constitution of Namibia, 1990.

Constitution of the Islamic Republic of Pakistan, 1973.

Constitution of Peru, 1993.

Constitution of the Republic of Poland, 1997.

Constitution of the Republic of South Africa, 1996.

Constitution of the Republic of Uganda, 1995.

Constitution of the Russian Federation, 1993.

Constitution of Syrian Arabic Republic, 2012.

Constitution of Sri Lanka, 1978.

Constitution of Sudan, 2005.

Constitution of Tunisia, 2014.

Criminal Code of Croatia 111 of 15 July 2003.

Criminal Code of the Democratic Republic of the Congo, 2005.

Criminal Code of the Czech Republic Act 40 of 2009.

Criminal Code of the Republic of Albania, Law no 7895 of 1995.

Criminal Code of the Russian Federation no 63-Fz of 13 June 1996.

Criminal Code of Ukraine, 2001.

Criminal-Procedural Code of the Russian Federation No. 174-Fz of 18 December 2001.

Dominican Suppression of the Financing of Terrorism (Amendment) Act 10 of 2011.

Egyptian Anti-Terrorism Law, 2015.

Ethiopian Anti-Terrorism Proclamation no 652 of 2009.

French Penal Code, 1791.

18 US Code $\$ 2340$ (2004).

Ghana Anti-Terrorism Act 762 of 2008.

Guatamalan Criminal Code, 1973.

Honduras Criminal Code (approved by decree 144-83), 1983.

Iraq Penal Code, 1969.

Jamaican Terrorism Prevention Act, 2005

Kazakstan Criminal Code, Law no 167 of 16 July 1997.

Kenya National Intelligence Service Act 28 of 2012.

Kenya National Police Service Act of 2011.

Law No. 96-06 of 18 January 1996.

Lesotho Penal Code Act 6 of 2012.

Published by Palacký University Olomouc, Czech Republic, 2018.

ISSN (print): 1213-8770; ISSN (online): 2464-6601 
Malaysian Penal Code Act 574 of 2015.

Mexico Federal Act on the Prevention and Punishment of Torture, 1991.

Netherlands Crimes of Terrorism Act, 2004.

New Zealand Terrorism Suppression Act, 2002.

Nigerian Terrorism (Prevention) Act, 2011.

Penal Code of Algeria, 1966.

Penal Code of Bhutan, 2008.

Penal Code of the Democratic Republic of Timor Leste 19 of 2009.

Penal Code of Spain, 1995 (as amended by Organic Law 5/2010.

Philippines Anti-Torture Act, 2009.

Saudi-Arabia Penal Law for Crimes of Terrorism and its Financing, 2013.

Seychelles Prevention of Terrorism Act 7 of 2004

South African Prevention of Combating and Torture of Persons Act, 2013.

South African Protection of Constitutional Democracy Against Terrorist and Related Activities Act 33 of 2004.

Sri Lanka Convention against Torture Act and Other Cruel, Inhuman or Degrading Treatment or Punishment, 1994.

Tanzanian Prevention of Terrorism Act, 2002.

Trinidad and Tobago Anti-Terrorism Act 26 of 2005.

Tunisia Anti-Terrorism Law 26 of 2015.

Turkish Penal Code, 2004.

Uganda Prevention and Prohibition of Torture Act, 2012.

Uganda Anti-Terrorism Act, 2002.

UK Criminal Justice Act, 2017.

Vanuatu Penal Code [Cap 135] 1981.

Venezuela Penal Code, 2000.

\section{Reports}

Analytical Report of the Study Group of the International Law Commission finalised by Chairman Martti Koskenniemi. Fragmentation of International Law: Difficulties Arising from the Diversification and Expansion of International Law, UN Doc A/CN4/L682, 13 April 2006, p. 92, 194.

Interim report of the Special Rapporteur on Torture and Other Cruel, Inhuman or Degrading Treatment or Punishment, Manfred Nowak, 28 July 2008, A63/175, para 46.

Report of the Special Rapporteur on Torture and Other Cruel, Inhuman or Degrading Treatment or Punishment, P Kooijmans, UN Doc E/CN4/1986/15 (1986) 1, para 3.

Report of the Special Rapporteur on Torture and Other Cruel, Inhuman or Degrading Treatment or Punishment, Nils Melzer, appointed by UNHRC resolution 1985/33, A/HRC/34/54, 14 February 2017, Yearbook of the International Law Commission II para 14.

Report of the Working Group on a Draft Convention against Torture and Other Cruel, Inhuman or Degrading Treatment or Punishment E/CN4/L1470, 12 March 1979, E/CN4/L1470, Agenda item 10(a), para 21.

Stanford Encyclopaedia of Philosophy. The History of Utilitarianism, 27 March 2009

Published by Palacký University Olomouc, Czech Republic, 2018.

ISSN (print): 1213-8770; ISSN (online): 2464-6601 
[online]. Available at: https://plato.stanford.edu/entries/utilitarianism-history/. Accessed: 24 June 2018.

The Guardian 'Israeli Government Report admits Systematic Torture of Palestinians' https://www.theguardian.com/world/2000/feb/11/israel (accessed 13 August 2017). See further Commission of Inquiry into the Methods of Investigation of the General Security Service Regarding Hostile Terrorist Activity (1989) https://www. cambridge.org/core/journals/israel-law-review/article/commission-of-inquiryinto-the-methods-of-investigation-of-the-general-security-service-regardinghostile-terrorist-activity/2feeb59b40b66a41e9ff3633c0d3bf69 (accessed 26 October 2017)

TLADI, Dire. Second report on Jus Cogens.' In UN Report of the International Law Commission $69^{\text {th }}$ session (1 May - 2 June and 3 July -4 August 2017) A/CN4/706, p. 9 para 18 .

Torture and Other Cruel, Inhuman or Degrading Treatment or Punishment, report by Special Rapporteur, Mr P Kooijmans, UN Doc E/CN4/1986/15 (1986) 1 para 3.

\section{Dissertations}

DE BEER, Aniel. Peremptory norms of General International law (Jus Cogens) and the Prohibition of Terrorism. Unpublished doctoral thesis, 2018, chapter 4, on file with author.

OECHMICHEN, Anna. Terrorism and Anti-Terrorism legislation: The Terrorised Legislator? Doctoral Thesis, Leiden University, 2009, pp. 338-342. Available at: http://hdl.handle.net/1887/13852. Accessed: 1 July 2017.

\section{Online}

AL JAZEERA. At least 11 civilians killed in Boko Haram attack, 2 September 2017, [online]. Available at: http://www.aljazeera.com/news/2017/09/11-civilianskilled-boko-haram-attack-170902043943431.html. Accessed: 1 October 2017.

AL JAZEERA. Kenya: Nine beheaded in suspected al-Shabab attack, 9 July 2017, [online]. Available at: http://www.aljazeera.com/news/2017/07/kenyaattack-170708103555604.html. Accessed: 1 October 2017.

Amnesty International. Spain: Civil Guards Convicted of Torture, 10 January 2011, http://www.amnesty.org/en/library/asset/EUR41/002/2011/en/60b24c89-11154124-aa36-68f3705efc84/eur410022011en.html (accessed 1 May 2017).

Amnesty International. Torture in 2014: 30 Years of Broken Promises, 5 December 2014. [online]. Available at: https://www.amnestyusa.org/sites/default/files/ act400042014en.pdf. Accessed: 2 April 2016.

Arab Government and Media Reactions to the Orlando Attack, 15 June 2016, [online]. Available at: http://www. washingtoninstitute.org/policy-analysis/ view/arab-government-and-media-reactionsto-the-orlando-attack. Accessed 7 August 2016.

BBC NEWS. Donald Trump says he believes waterboarding works, 26 January 2017, [online]. Available at: https://www.bbc.com/news/world-us-canada-38753000 [online]. Accessed: 16 June 2018.

BBC NEWS. Israel Admits Torture, 9 February 2000, [online]. (2000). Available at: http://news.bbc.co.uk/2/hi/middle_east/637293.stm. Accessed: 12 August 2017.

Published by Palacký University Olomouc, Czech Republic, 2018.

ISSN (print): 1213-8770; ISSN (online): 2464-6601 
BBC NEWS. London Bridge attack: timeline of British terror attacks, 19 June 2017, [online]. Available at: http://www.bbc.com/news/uk-40013040. Accessed: 1 October 2017.

BERI, Ruchita. Rise of Terrorism in Africa. Institute for Defence Studies and Analyses, 13 April 2017, [online]. Available at: http://www.idsa.in/idsacomments/rise-ofterrorism-in-africa_rberi_130417. Accessed: 1 October 2017.

BUSINESS INSIDER. These Are The 13 'Enhanced Interrogation Techniques' the CIA Used On Detainees, 10 December 2014, [online]. Available at: http://www.businessinsider.com/the-13-enhanced-interrogation-techniques-the-cia-used-ondetainees-2014-12?IR=T. Accessed: 30 June 2018.

BUSINESS INSIDER. Trump says torture absolutely works, 25 June 2017, [online]. Available at: www.businessinsider.com/trump-says-torture-absolutelyworks-2017-1. Accessed: 16 June 2018.

BVerfG, Judgment of the First Senate of 15 February 2006, 1 BvR 357/05, paras 1-156. [online]. Available at: https://www.bundesverfassungsgericht.de/SharedDocs/Entscheidungen/EN/2006/02/rs20060215_1bvr035705en.html. Accessed: 24 June 2018.

Committee against Torture, Consideration of Reports Submitted by States Parties Under Article 19 of the Convention: Conclusions and recommendations of the Committee Against Torture, UN Doc. A/52/44, 10 September 1997, [online]. Available at: https://unispal.un.org/DPA/DPR/unispal.nsf/0/CA3A3721CCF0729B05256545005095B0. Accessed: 30 June 2018.

Consideration of reports submitted by state parties under article 19 of the Convention, Croatia, UN Doc CAT/C/54/Add3 12, 6-7 May 2004, [online]. Available at: http://www.unhchr.ch/tbs/doc.nsf/(Symbol)/CATC54Add3En?OpenDocument. Accessed: 17 June 2018.

Consideration of reports submitted by state parties under article 19 of the Convention, Egypt, UN Doc CAT/C/34/Add.11, 28 January 1999, [online]. Available at: www.unhchr.ch/tbs/doc.nsf/(Symbol)/CATC34.Add.11.En?OpenDocument. Accessed: 1 May 2017.

Consideration of Reports Submitted by State Parties under Article 19 of the Convention, Greece, UN Doc CAT/C/61/Add.2, 16 February 2004 [online], p. 230. Available at: www.unhchr.ch/tbs/doc.nsf/(Symbol)/CAT.C.61.Add.1.En?Opendocument. Accessed: 6 May 2017.

Consideration of Reports Submitted by State Parties under Article 19 of the Convention, Latvia, UN Doc CAT/C/21/Add.4 6. [online]. Available at www.unhchr.ch/tbs/ doc.nsf/(Symbol)/CAT.C.21.Add.4.En?OpenDocument. Accessed: 6 May 2017.

Consideration of Reports Submitted by State Parties under Article 19 of the Convention, Luxembourg, UN Doc CAT/C/SR.517 [online]. Available at: www.unhchr. ch/tbs/doc.nsf/(Symbol)/4870d067077d49bac1256a26004c2298?Open document. Accessed: 1 May 2017.

Convention against Torture and Other Cruel, Inhuman or Degrading Treatment or Punishment, Reservations, Understandings and Declarations Made by the United States of America. [online]. Available at: http://www.unhchr.ch/tbs/doc.nsf/0/5d 7ce66547377b1f802567fd0056b533?Open Document. Accessed: 12 August 2017. G20 Statement on the Fight Against Terrorism, [online]. Available at: http://www.

Published by Palacký University Olomouc, Czech Republic, 2018.

ISSN (print): 1213-8770; ISSN (online): 2464-6601 
consilium.europa.eu/en/meetings/internationalsummit/2015/11/g20-statementon-the-fight-against-terrorism_pdf/. Accessed: 7 August 2016.

FARMER, John J Jr., NEAFSEY, Edward M. Trump and the Law on Torture, 1 March 2018, [online]. Available at: https://www.lawfareblog.com/trump-and-law-torture. Accessed: 16 June 2018.

FOX NEWS. Al-Shabab fighters attack African Union convoy in southern Somalia, killing at least 8, 30 July 2017, [online]. Available at: http://www.foxnews.com/ world/2017/07/30/al-shabab-fighters-attack-african-union-convoy-in-southern-somalia-killing-at-least-8.html. Accessed: 1 October 2017.

ICRC. France: Practice Relating to Rule 90. Torture and Cruel, Inhuman or Degrading Treatment. Available at: https://ihl-databases.icrc.org/customary-ihl/eng/ docs/v2_cou_fr_rule90. Accessed 1 July 2018.

ICRC. Report of the International Committee of the Red Cross (ICRC) on the Treatment by the Coalition Forces of Prisoners of War and Other Protected Persons by the Geneva Conventions in Iraq During Arrest, Internment and Interrogation, 2004, [online]. Available at: http://www.derechos.org/nizkor/us/doc/icrc-prisoner-report-feb-2004.pdf. Accessed: 7 October 2012, p. 8.

ICRC. Report on the Treatment of Fourteen 'High Value Detainees' in CIA Custody, 2007, [online]. Available at: http://assets.nybooks.com/media/doc/2010/04/22/ icrc-report.pdf. Accessed: 7 October 2017, p. 12.

Investigation of the 800th Military Police Brigade - the Taguba Report: a Report prepared by Maj.Gen. AM Taguba on Alleged Abuse of Prisoners by Members of the 800th Military Police Brigade at the Abu Ghraib Prison, Baghdad. [online]. Available at: https://fas.org/irp/agency/dod/taguba.pdf. Accessed: 16 April 2017.

LEVIN, Michael. The Case for Torture, 1982 [online]. Available at: http://people. brandeis.edu/ teuber/torture.html. Accessed: 5 September 2017.

Public Broadcasting Service. Trump formally nominates Gina Haspel to be next CIA director, 17 April 2018, [online]. Available at https://www.pbs.org/newshour/politics/trump-formally-nominates-gina-haspel-to-be-next-cia-director. Accessed on: 16 June 2018.

Report of the Inter-American Commission on Human Rights Right to Humane Treatment, para 164, [online]. Available at: http://www.cidh.oas.org/Terrorism/ Eng/part.f.htm\#_ftn418. Accessed: 3 October 2017.

SHUGERMAN, Emily. Gina Haspel: Who is the woman Donald Trump wants to take over the CIA? 11 May 2018, [online]. Available at: https://www.independent. co.uk/news/world/americas/us-politics/gina-haspel-cia-director-donald-trumpnominated-mike-pompeo-rex-tillerson-a8346556.html. Accessed: 16 June 2018.

Summary Records of the Sixth Committee, $52^{\text {nd }}, 55^{\text {th }}, 56^{\text {th }}$ and $66^{\text {th }}$ sessions Official Records of the General Assembly [online]. Available at: http://www.un.org/law/ cod/sixth. Accessed: 8 August 2017.

THE GUARDIAN. Torture techniques Endorsed by the Bush Administration, 17 April 2009, [online]. (2009). Available at: https://www.theguardian.com/world/2009/ apr/17/torture-methods-interrogation-george-bush-approved. Accessed: 12 August 2017.

POLLOCK, David \& ABDELAZIZ, Mohamed. Arab states condemn "terrorist" Paris attacks [online]. Available at: http://english.alarabiya.net/en/News/middle-

Published by Palacký University Olomouc, Czech Republic, 2018.

ISSN (print): 1213-8770; ISSN (online): 2464-6601 
east/2015/11/14/Arab-statesdenounce-Paris-attacks-as-violation-of-human-values-.html. Accessed: 1 December 2016.

THE NEW ZEALAND HERALD. Donald Trump May be Seeking to Reinstate Torture Methods for Detained Terrorist Suspects, 26 January 2017, [online]. Available at: https://www.nzherald.co.nz/world/news/article.cfm?c_id=2\&objectid=11789393. Accessed: 12 August 2017.

TIME MAGAZINE. A Timeline of recent terror attacks in Europe, 20 December 2016, [online]. Available at: http://time.com/4607481/europe-terrorism-timeline-berlin-paris-nice-brussels/. Accessed: 1 October 2017.

Transcript of US Joint Congressional hearing. Extraordinary Rendition in US Counterterrorism Policy: The Impact on Transatlantic Relations. Subcommittee on International Organizations, Human Rights and Oversight and Subcommittee on Europe, 17 April 2007, [online]. Available at: http://foreignaffairs.house.gov/ hearing_notice.asp?id=803. Accessed: 1 June 2018.

TRUMP, Donald J. National Security Strategy of the United States of America. December 2016, [online]. Available at: https://www.whitehouse.gov/wp-content/ uploads/2017/12/NSS-Final-12-18-2017-0905-2.pdf. Accessed: 16 June 2018.

UN Committee Against Torture. General Comment No. 2: Implementation of Article 2 by States Parties. 24 January 2008, CAT/C/GC/2, [online]. Available at: http:// www.refworld.org/docid/47ac78ce2.html. Accessed: 30 June 2018.

UN Committee against Torture, Report on Argentina, UN Doc A/45/44, 21 June 1990, para 154, [online]. Available at: https://digitallibrary.un.org/record/97924. Accessed: 30 June 2018.

US Army Field Manual, viii FM2-22.3. Human Intelligence Collector Operations, pp. 20-25. [online]. September 2006. Available at: https://fas.org/irp/doddir/army/ fm2-22-3.pdf. Accessed: 17 June 2018.

United Nations Treaty Ratifications. [online]. Available at: https://treaties.un.org/ Pages $/$ ViewDetails.aspx? src=IND\&mtdsg_no=IV-9\&chapter $=4 \&$ lang $=$ en . Accessed: 17 June 2018.

US Department of State. Initial Report of the United States of America to the UN Committee against Torture, 15 October 1999, p. 6. Available at: https://1997-2001. state.gov/global/human_rights/torture_index.html. Accessed: 1 July 2018.

US Department of State. Second Periodic Report of the United States of America to the UN Committee against Torture, 6 May 2005, pp. 4, 17. Available at: https://www. state.gov/j/drl/rls/45738.htm. Accessed: 1 July 2018.

US Department of State. United States Condemns Terrorist Attack on Istanbul's Ataturk Airport, [online]. 28 June 2016. Available at: http://www. state.gov/r/pa/prs/ ps/2016/06/259153.htm. Accessed 7 August 2016.

Washington Post. US Decries Abuse but Defends Interrogations, 26 December 2000, [online]. Available at: https://www.washingtonpost.com/. Accessed: 16 June 2018.

Published by Palacký University Olomouc, Czech Republic, 2018.

ISSN (print): 1213-8770; ISSN (online): 2464-6601 